\title{
Soil Respiration Characteristics and Influencing Factors for Apple Orchards in Different Regions on the Loess Plateau of Shaanxi Province
}

\author{
Tingting Hou ${ }^{1}$, Yanping Wang ${ }^{1,2, *}$, Fuxing Guo ${ }^{1}$, Qiong Jia ${ }^{1}$, Xinnan Wu ${ }^{1}$, Enguang Wang ${ }^{1}$ and Jingbo Hong ${ }^{1}$ \\ 1 College of Natural Resources and Environment, Northwest A\&F University, Yangling 712100, China; \\ m15754368783@163.com (T.H.); fuxing.guo@nwafu.edu.cn (F.G.); j872464144@163.com (Q.J.); \\ 13204791095@163.com (X.W.); wang18438616590@163.com (E.W.); 17519519106@163.com (J.H.) \\ 2 Key Laboratory of Plant Nutrition and the Agri-Environment in Northwest China, Ministry of Agriculture, \\ Yangling 712100, China \\ * Correspondence: ylwangyp@163.com
}

Citation: Hou, T.; Wang, Y.; Guo, F.; Jia, Q.; Wu, X.; Wang, E.; Hong, J. Soil Respiration Characteristics and Influencing Factors for Apple Orchards in Different Regions on the Loess Plateau of Shaanxi Province. Sustainability 2021, 13, 4780. https:// doi.org/10.3390/su13094780

Academic Editor: Rajan Ghimire

Received: 5 March 2021

Accepted: 22 April 2021

Published: 24 April 2021

Publisher's Note: MDPI stays neutral with regard to jurisdictional claims in published maps and institutional affiliations.

Copyright: (c) 2021 by the authors. Licensee MDPI, Basel, Switzerland. This article is an open access article distributed under the terms and conditions of the Creative Commons Attribution (CC BY) license (https:// creativecommons.org/licenses/by/ $4.0 /)$.

\begin{abstract}
To explore the characteristics of the spatial and temporal variation in soil respiration (SR) in orchard ecosystems in different regions of the Loess Plateau of Shaanxi Province and to distinguish the controlling factors, representative orchards were studied from April to October 2019. We conducted SR measurements in five locations, including Mizhi dangta (MZ), Ansai Liuzhuang (AS), Luochuan houzitou (LC), Fuping meijiaping (FP), and Yangling Wuquan (YL). The results indicated that the SR of each orchard showed clear seasonal variation. The SR increased with the distance from the trunk at the tree scale, while gradually increasing from north to south on the regional scale $(p<0.05)$. The soil temperature and soil moisture were the main factors controlling the seasonal changes in SR in the orchards. On the tree scale, the fine root biomass was the main factor causing the tree-scale spatial variability. At the regional scale, SR was mainly influenced by the differences in the soil temperature, soil moisture, soil organic carbon, soil bulk density and $\mathrm{pH}$. In agricultural management practices, the cumulative soil respiration was higher with irrigated treatment than with non-irrigated (NI) treatment $(p<0.05)$. In addition, traditional surface drip irrigation (SDI) and root injection irrigation (RII) showed great differences in soil respiration in the early and late stages of irrigation $(p<0.05)$, and the soil moisture was the main controlling factor. Compared with no tillage (NI), green cover (GC), deep tillage (DT), and shallow tillage (ST) increased the SR by $57 \%, 36 \%$ and $14 \%$, respectively $(p<0.05)$. Due to the great temporal and spatial variation in the SR in our study area, we determined that the soil respiration in the orchards was affected not only by environmental factors but also by agricultural measures. Therefore, greater attention should be paid to human factors when exploring SR to ensure that orchard management can promote the economic benefits of the orchards without greatly impacting the environment.
\end{abstract}

Keywords: soil respiration; soil temperature; soil moisture; fine root biomass; orchards

\section{Introduction}

Soil respiration (SR) is the main mechanism by which terrestrial ecosystems release $\mathrm{CO}_{2}$ to the atmosphere. Small changes in SR can also have a significant impact on $\mathrm{CO}_{2}$ concentrations in the global atmosphere [1,2]. The accurate quantification of carbon emissions through SR is of great significance for understanding climate change and the carbon cycle [3].

Soil respiration is affected by many factors, such as the soil temperature, soil moisture, soil properties, fine root biomass, and agricultural practice measures [4-8]. Soil temperature and moisture are generally considered to be the main driving forces of the seasonal variation in SR $[9,10]$. On the one hand, soil temperature and moisture affect the soil microbial respiration by affecting the decomposition rate of soil organic matter; on the other hand, 
they also affect root respiration by affecting root growth and metabolism [11,12]. Soil temperature is the most important factor and has an impact on almost all aspects of the respiration process [13-15]. Soil respiration has a strong exponential relationship with the soil temperature $[16,17]$. Soil moisture is also an important factor affecting SR; however, the driving effect of soil moisture on SR is complex [18]. The spatial variation in SR at the tree scale is typically significantly correlated with the fine root biomass. Although there are exceptions, the fine root biomass does not change with increasing distance from trees [19]. However, in general, the fine root biomass varies with the distance from the trunk, being higher closer to the trunk [13,20-22]. Land use types and soil management (such as irrigation, farming, and mulching), and plant transmission factors may play an important role in the spatial variability of SR. Structural heterogeneity (such as the planting density and canopy expansion) may lead to significant differences when estimating the amount of soil respiration at the orchard scale [23-25]. The temperature sensitivity of soil respiration $\left(\mathrm{Q}_{10}\right)$ is an efficient parameter used to evaluate the feedback relationship between global climate change and the terrestrial carbon cycle [26,27]. The $Q_{10}$ values of $S R$ in different ecosystems or vegetation types and different regions of the same vegetation are different and vary greatly $[28,29]$. The factors influencing the spatial variability of SR at the regional scale are more complex, being affected by the climate, soil (such as the soil texture, bulk density, organic carbon, $\mathrm{pH}$, etc.), and human factors [30]. Therefore, conducting studies in different regions is crucial.

The Loess Plateau is the largest and deepest loess deposit area in the world, with an area of $64 \times 104 \mathrm{~km}^{2}$, most of which is mountainous hills [31]. Apple orchards are the predominant type of land use in this region, with an area of about 15,000 km² in 2019 , and these play an essential role in the regional carbon cycling, potentially influencing the exchange rates of $\mathrm{CO}_{2}$ flux between soil and the atmosphere in terrestrial ecosystems. Compared with forest ecosystems, orchards were mostly disturbed by human factors. Previous studies mainly focused on the temporal and spatial variability in SR at single-tree scale, the factors influencing this, and a comparison of soil respiration in orchards with other land use types. The apple orchard system on the Loess Plateau had a high carbon sequestration capacity [32], which is related to the change in land use in this area [6,33-35]. In addition, the temporal and spatial variability of SR will have an impact on carbon emission [36]. Wang et al. [9] studied the temporal and spatial variability in soil respiration at the tree scale. This is of great significance for the accurate estimation of carbon emissions. Our study aimed to reveal the soil respiration mechanism of apple orchards in different regions and evaluate the effects of natural and human factors on soil carbon release through high-frequency monitoring of the soil respiration process on the Loess Plateau. Therefore, it is necessary to estimate the carbon emissions of orchard ecosystems and the factors influencing it, which are of strategic significance to correctly evaluate the carbon emissions of terrestrial ecosystems in China. However, the climatic, soil, and planting patterns of apple orchards in different regions were very different, and there is a lack of cross-sectional comparative studies on the characteristics of SR and the factors influencing this in different regions. Comparative studies of SR can fully reveal the differences in the soil respiration in different regions [37-39], and quantifying the temporal and spatial variation in the SR and its controlling factors can provide an SR theoretical basis for the carbon emission estimation of apple orchards ecosystems.

In this study, according to the different characteristics of the apple orchard distribution, soil, climate and planting pattern in the Loess Plateau of Shaanxi Province, five orchards in five regions were selected as the research objects from south to north. The purpose was to (1) compare differences in the temporal and spatial variability in the SR in apple orchards of different regions, and explore its controlling factors, (2) clarify the spatial variation characteristics of the SR on a large regional scale and the relationship between the SR and the climate, soil, and apple cultivation patterns, and (3) evaluate the variation in SR under agricultural management practices. In the context of global climate change, our results are 
of great significance for improving the carbon emission estimation of orchard ecosystem in the Loess Plateau of China.

\section{Materials and Methods}

\subsection{Area Description}

The study area is located in a typical Loess Plateau in the north-central part of Shaanxi Province in China (34-38 N, 106-111 ${ }^{\circ} \mathrm{E}$ ), covering an area of $130,000 \mathrm{~km}^{2}$ (Figure 1). The northern terrain is hilly and gully, the middle is tableland-gully, and the south is plain. This area has a continental monsoon climate characterized by a seasonal monsoon rhythm with hot summers and cold winters. The annual average temperature is $8-13.5^{\circ} \mathrm{C}$ decreasing from south to north; July and August have high-temperature weather, and the frost-free period is $160-215$ days. The annual mean precipitation gradually decreases from south to north (700-400 $\mathrm{mm}$ ), precipitation mainly occurs in the autumn, and the drought in spring and summer is more serious. The soil types include Loessi-Orthic Primosols, Cumulic Haplustolls, and Eum-Orthric Anthrosols according to the American system of soil classification. From south to north, the sand content increases, the soil bulk density and soil organic matter content decrease, and soil erosion intensifies.

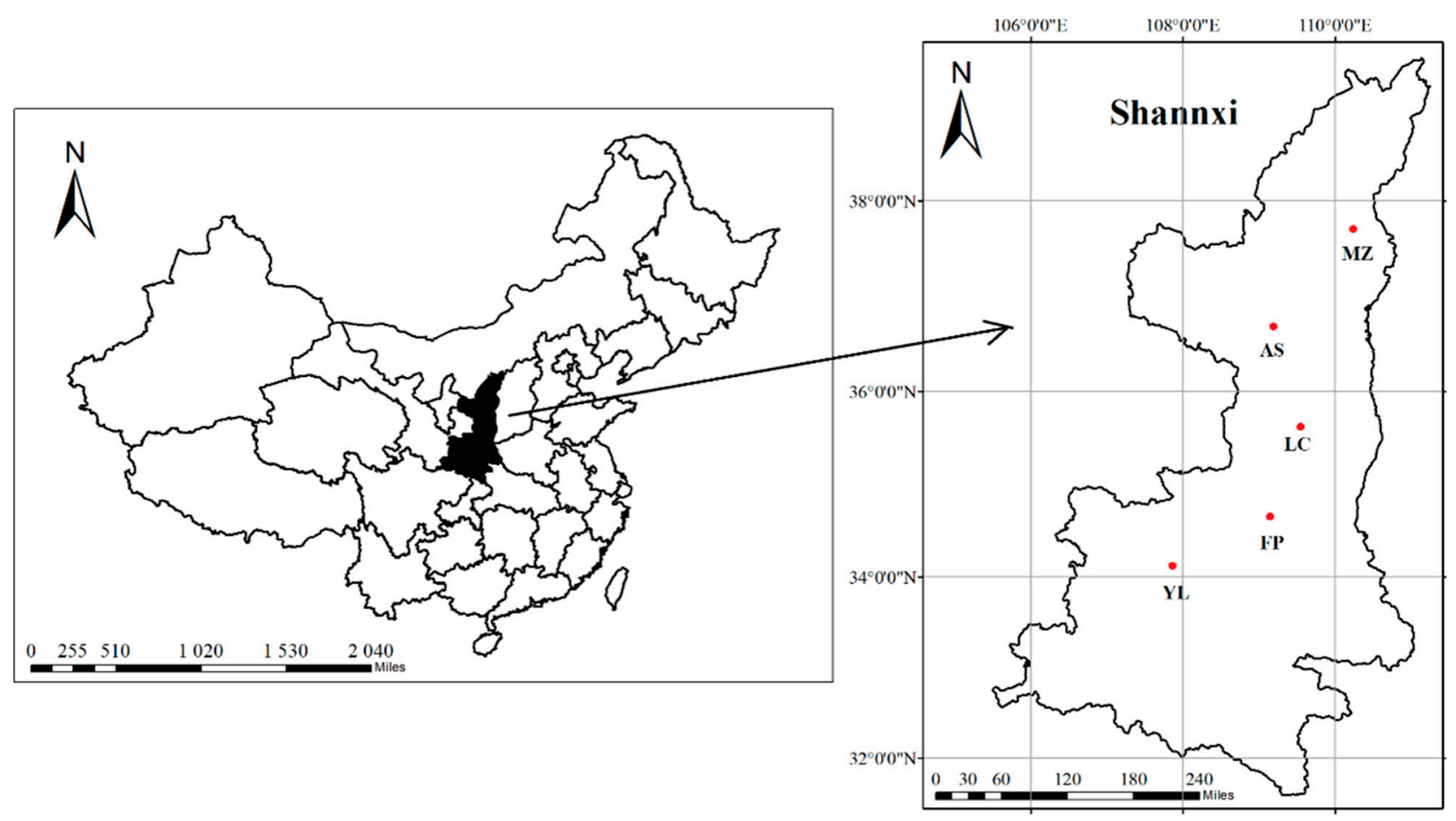

Figure 1. The spatial distribution of the orchards. Mizhi dangta (MZ), Ansai Liuzhuang (AS), Luochuan houzitou (LC), Fuping meijiaping (FP), and Yangling Wuquan (YL).

Based on the analysis of apple distribution and a comprehensive field survey in Shaanxi Province, five representative mature apple orchards (apple trees with similar heights and crown volumes) were selected from north to south, including Mizhi dangta (MZ) and Ansai Liuzhuang (AS) in the hilly and gully region, Luochuan houzitou (LC) in the tableland-gully region, and Fuping meijiaping (FP) and Yangling Wuquan (YL) counties in the plain region (Figure 1, Table 1). The variations in the temperature and rainfall of the apple-tree-growing season in the five regions are shown in Figure 2. The trees were planted at a spacing of 5 (inter-row) $\times 4$ (intra-row) $\mathrm{m}$ in MZ, AS, and LC, and at $4 \times 2$ $\mathrm{m}$ and $4 \times 1 \mathrm{~m}$ in FP and $\mathrm{YL}$, respectively. Vegetation was not planted between the rows of MZ, AS, and LC, and clover was planted between the rows of YL and FP. The apple cultivar was Red Fuji at all locations. 
Table 1. The geographic characteristics of the orchards.

\begin{tabular}{|c|c|c|c|c|c|c|c|c|c|c|}
\hline Location & $\begin{array}{l}\text { Latitude } \\
\text { (N) }\end{array}$ & $\begin{array}{l}\text { Longitude } \\
\text { (E) }\end{array}$ & $\begin{array}{l}\text { Elevation } \\
\text { (m) }\end{array}$ & Terrain & Soil Types & $\begin{array}{l}\text { Annual } \\
\text { Mean Pre- } \\
\text { cipitation } \\
(\mathrm{mm})\end{array}$ & $\begin{array}{c}\text { Annual } \\
\text { Average } \\
\text { Temperature } \\
\left({ }^{\circ} \mathrm{C}\right)\end{array}$ & Tree-Age & $\begin{array}{c}\text { Space } \\
(\mathbf{m} \times \\
\mathbf{m})\end{array}$ & $\begin{array}{c}\text { Cultivation } \\
\text { Modes }\end{array}$ \\
\hline $\mathrm{MZ}$ & $37^{\circ} 47^{\prime} 8^{\prime \prime}$ & $110^{\circ} 5^{\prime} 29^{\prime \prime}$ & 1030 & Platform & $\begin{array}{l}\text { Loessi- } \\
\text { Orthic } \\
\text { Primosols }\end{array}$ & 451.6 & 8.5 & 10 & $5 \times 4$ & Standard \\
\hline AS & $36^{\circ} 47^{\prime} 23^{\prime \prime}$ & $109^{\circ} 22^{\prime} 42^{\prime \prime}$ & 1220 & Platform & $\begin{array}{l}\text { Loessi- } \\
\text { Orthic } \\
\text { Primosols }\end{array}$ & 506.6 & 9.1 & 11 & $5 \times 4$ & Standard \\
\hline $\mathrm{LC}$ & $35^{\circ} 46^{\prime} 2^{\prime \prime}$ & $109^{\circ} 26^{\prime} 28^{\prime \prime}$ & 1160 & Highland & $\begin{array}{l}\text { Cumulic } \\
\text { Haplus- } \\
\text { tolls }\end{array}$ & 622 & 9.2 & 16 & $5 \times 4$ & Standard \\
\hline $\mathrm{FP}$ & $34^{\circ} 50^{\prime} 17^{\prime \prime}$ & $109^{\circ} 0^{\prime} 47^{\prime \prime}$ & 570 & Plain & $\begin{array}{c}\text { Eum- } \\
\text { Orthric } \\
\text { Anthrosols }\end{array}$ & 533.2 & 13.1 & 13 & $4 \times 2$ & Dwarfing \\
\hline YL & $34^{\circ} 18^{\prime} 28^{\prime \prime}$ & $108^{\circ} 0^{\prime} 15^{\prime \prime}$ & 550 & Plain & $\begin{array}{c}\text { Eum- } \\
\text { Orthric } \\
\text { Anthrosols }\end{array}$ & 649.5 & 12.9 & 9 & $4 \times 1$ & Dwarfing \\
\hline
\end{tabular}

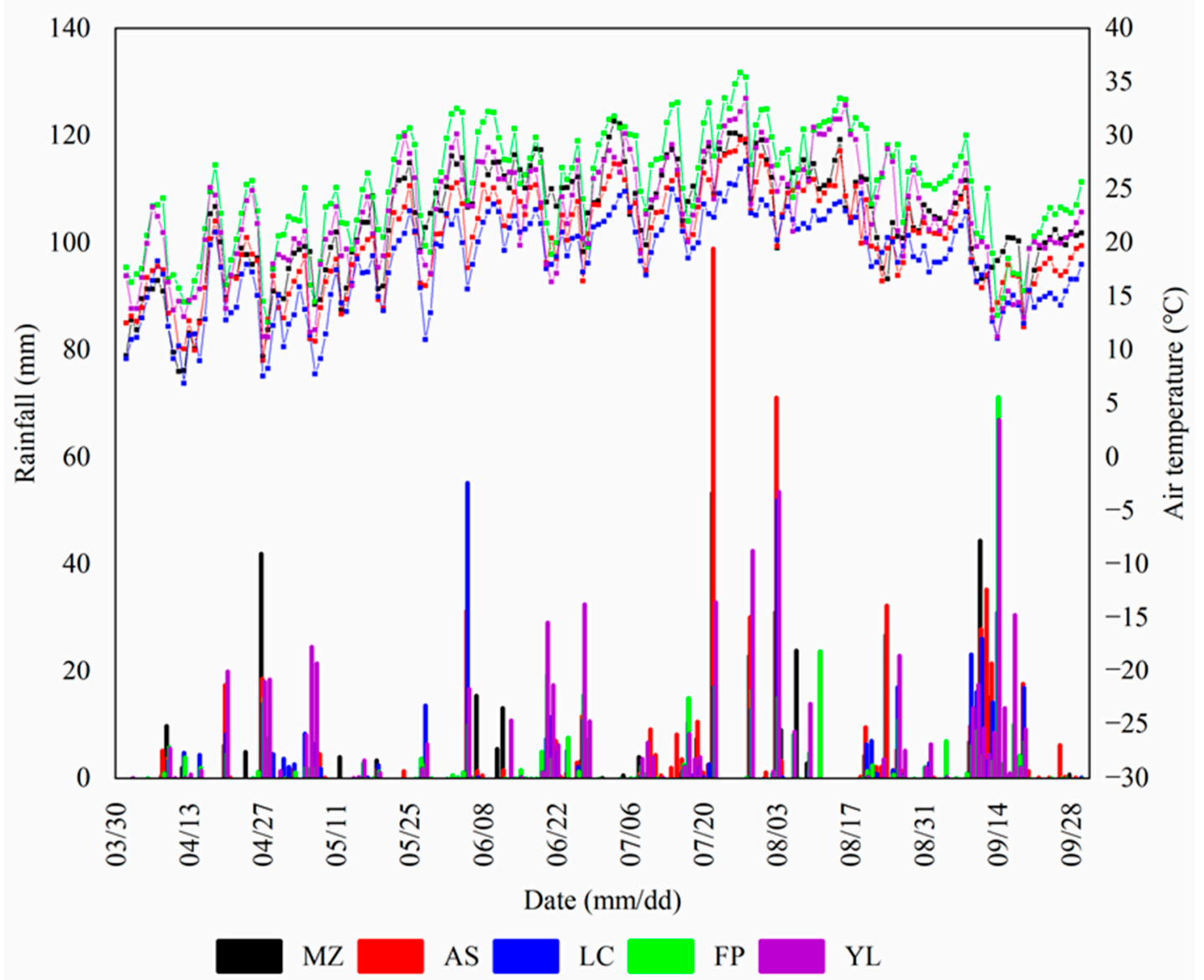

Figure 2. The variations in temperature and rainfall of the apple tree growing season in the five regions (the bar chart shows rainfall, and the line chart shows the air temperature).

\subsection{Experimental Design and Measurement}

In the center of each of the experimental orchards, the four PVC pipes (which were used to measure soil respiration) with a diameter of $20 \mathrm{~cm}$ and a height of $10 \mathrm{~cm}$ (p1, p2, $\mathrm{p} 3$, and $\mathrm{p} 4$ ) were perpendicular to the row direction, and their distances from the sample tree (tree 1) trunk were 50,100, 150, and $200 \mathrm{~cm}$, respectively. p5 was arranged along the row with a distance of $200 \mathrm{~cm}$ from $\mathrm{p} 4$, and the distance from the sample tree (tree 1) trunk 
was $283 \mathrm{~cm}$. p6 was arranged along the row with a distance of $150 \mathrm{~cm}$ from $\mathrm{p} 3$, and the distance from the sample tree (tree 1) trunk was $212 \mathrm{~cm}$ in MZ, AS, and LC. Due to the row spacing and plant spacing in FP and YL orchards were $4 \times 2,4 \times 1$, and the plant spacing was too close, nearby trees would have an impact on the measurement of soil respiration in tree 1. Therefore, $\mathrm{p} 5$ and $\mathrm{p} 6$ were not placed. All PVC pipes were inserted into the soil at a depth of $7 \mathrm{~cm}$ (Figure 3).

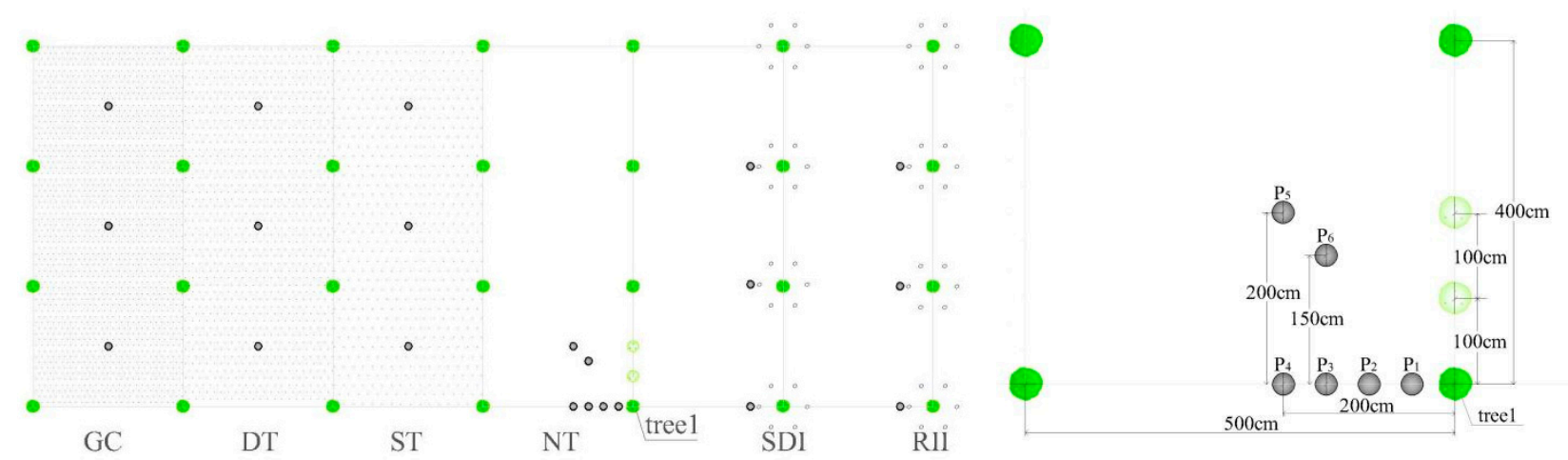

Figure 3. Schematic diagram of the test layout. $500 \mathrm{~cm}$ is the inter-row spacing, and $400 \mathrm{~cm}$ is the intra-row spacing. P1, P2, P3, P4, P5, P6 distances from the sample tree (tree 1) trunk were 50, 100, 150, 200,283, and $212 \mathrm{~cm}$, respectively. Light green trees represent trees $100 \mathrm{~cm}$ and $200 \mathrm{~cm}$ from tree 1 in YL and FP orchards, respectively. The diagram on the right shows the detailed experimental arrangement of the tree 1 on the left.

The SR, 5-cm soil temperature, and soil moisture were measured from 09:00 to 11:00 $h$ in sunny weather and the observed value of the soil respiration rate during this period was consistent with the daily average value [6]. From April to September 2019, the determination was conducted twice a month, for a total of 12 times. The SR was measured using a portable soil carbon flux meter Li-8100 (Li COR, Lincoln, NE, USA) (Figure 4). The Li-8100 uses the rate of increase in the indoor $\mathrm{CO}_{2}$ concentration to calculate and measure the rate of $\mathrm{CO}_{2}$ diffusion from the outdoor soil into the air. We inserted PVC tubes into the soil one week before the measurement. To avoid short-term fluctuations in the respiration rate caused by soil disturbance, measurements were made $24 \mathrm{~h}$ after the soil collars was placed, and all living bodies in the soil collars were removed before the measurement. The measurement time was limited to $0.5-3 \mathrm{~min}$ to ensure that the $\mathrm{CO}_{2}$ concentration change in the measurement chamber was as small as possible. On the date of the measurement in each area, a respirator was used to measure the PVC pipes. The soil temperature was measured by a soil thermometer (li-8100) [40]. The soil moisture was measured using the drying method, and soil samples of $0-5 \mathrm{~cm}$ depth were drilled near each PVC pipe.

After the monitoring of each month was completed, the surface litter was removed near the monitoring points in each sample plot, and then soil samples of 0-20 cm depth were drilled with the removal of stones and roots, placed into self-sealing bags, and labelled. The samples were taken back to the laboratory for natural air drying and screening, and then used to determine the soil organic carbon and $\mathrm{pH}$ value. The soil organic carbon was determined using the potassium dichromate external heating method, and the $\mathrm{pH}$ value was determined using the potentiometric method. The soil bulk density was determined using the ring knife method [41,42]. Ten sampling points were selected according to the shape of "S" in each apple orchard, and unmodified soil in the $0-10 \mathrm{~cm}$ soil layer was sampled. The fine root biomass was determined according to the method described by Zeng et al. [3], soil cores ( $9 \mathrm{~cm}$ in diameter and $20 \mathrm{~cm}$ in depth) were collected near each $P V C$ pipe at a depth of $0-20 \mathrm{~cm}$. The roots were washed and oven-dried to a constant weight at $60^{\circ} \mathrm{C}$ for $48 \mathrm{~h}$.

To clarify the impact of management measures on the soil respiration, irrigation and tillage tests were conducted in the apple orchard of MZ. In MZ, irrigation was more 
convenient, and there was no vegetation between the apple tree rows, making it easier to monitor soil respiration.

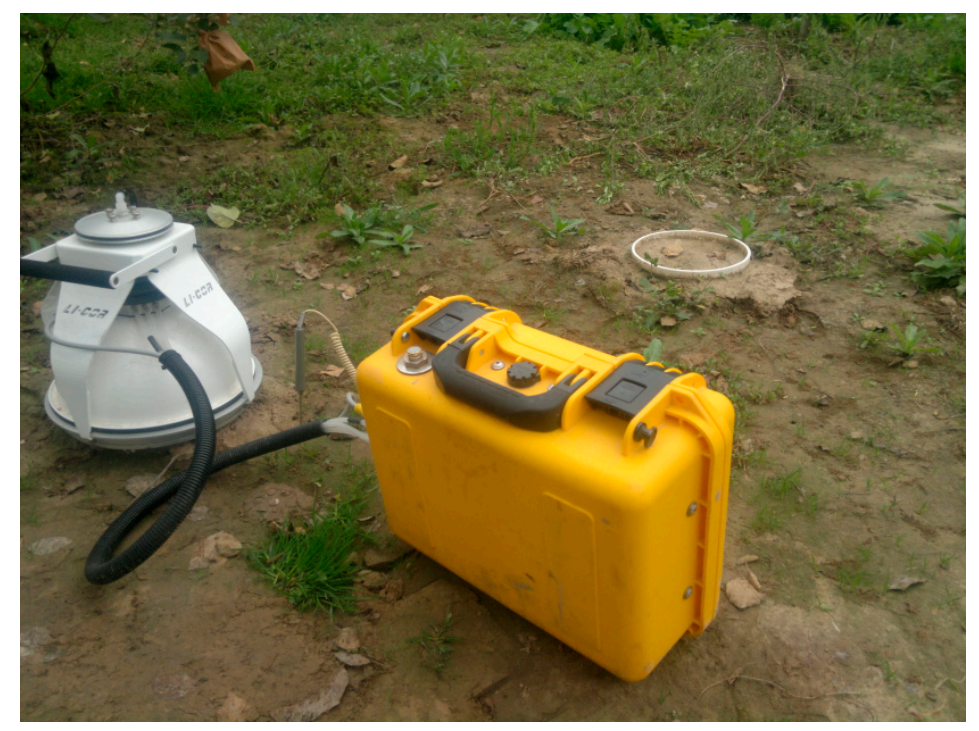

Figure 4. Portable soil carbon flux meter Li-8100.

Traditional surface drip irrigation (SDI), Root-zone injection irrigation (RII, Wang et al. [43]), and no irrigation (NI) were randomly distributed in the orchards. There were six test plots with 30 apple trees in each plot. The irrigation dates were 5 April, 15 May, and18 June, respectively, and the irrigation amounts were 33.8, 45.6, and $68.4 \mathrm{~mm} \mathrm{ha}^{-1}$, respectively. The SR was assessed the day before and two days after irrigation. The other assessment dates were on the 7th, 14th, and 21th day after irrigation in April, on the 4th, 7th, 14th, and 21st day in May, and on the 7th in June. On these days, the SR, soil temperature, and soil moisture were measured. Six PVC pipes were installed within each plot at a distance of $0.2 \mathrm{~m}$ from an RII system injection nozzle or an SDI system emitter (Figure 3).

Tillage. The experiment was conducted in four adjacent areas $(10 \times 3 \mathrm{~m})$ without vegetation and with cover crops planted. Three soil tillage treatments were used: (I) green manure mulching (GC), (II) deep tillage (DT) and (III) shallow tillage (ST). The fourth area had no tillage, representing a no-till (NT) treatment. Under other conditions, the tillage/mulch system was consistent with NT. All PVC pipes were placed at the center of four apple trees to avoid the influence of the root respiration of apple trees on the experiment, three PVC pipes were installed for each treatment (Figure 3). After a single tillage, the assessments were carried out on 17 days (April 04, 07, 08, 10, 12, 13, 14, 15, 19, $21,22,23,24,25,26,28$, and 29). On these days, the SR, soil temperature, and soil moisture were measured. In this study, these dates are identified as days after tillage (i.e., 1, 4, 5, 7, 9, $10,11,12,16,18,19,20,21,22,23,25$, and 26 days after tillage).

\subsection{Data Analysis}

A nonlinear regression function was used to describe the relationship between the SR and the soil temperature and soil moisture:

$$
\begin{gathered}
\mathrm{SR}=\alpha \mathrm{e}^{\beta \mathrm{T}_{5}} \\
\mathrm{SR}=\mathrm{a} \theta^{2}+\mathrm{b} \theta+\mathrm{c}
\end{gathered}
$$

where SR is the soil respiration rate $\left(\mu \mathrm{mol} \mathrm{m}{ }^{-2} \mathrm{~s}^{-1}\right), \mathrm{T}_{5}$ is the soil temperature at a $5-\mathrm{cm}$ depth $\left({ }^{\circ} \mathrm{C}\right), \theta$ is the soil moisture at a 5 -cm depth $(\%)$, and $\alpha, \beta, \mathrm{a}, \mathrm{b}$, and $\mathrm{c}$ are the regression coefficients. The SR, $\mathrm{T}_{5}$, and $\theta$ are the monthly average values from April to September 2019. Tukey test was used to test the coefficient values. 
The $\mathrm{Q}_{10}$ value was calculated according to the following equation:

$$
\mathrm{Q}_{10}=\mathrm{e}^{10 \beta} .
$$

The temporal and spatial variability in soil respiration were quantified with the coefficient of variation $(\mathrm{CV})$ :

$$
\mathrm{CV}=\text { Standard deviation } / \text { mean } \times 100 \% .
$$

The temporal variability in the soil respiration was based on the data from each region over the entire experimental period (April to September 2019), and the spatial variability of the soil respiration between the five regions was based on the data measured at each time point (12 collection dates from April to September 2019).

The cumulative soil respiration was calculated using the by interpolation method:

$$
\begin{gathered}
\mathrm{Di}=\mathrm{Rsi} \times 3600 \times 24 \times 12 \times 10^{-6} \\
\mathrm{CO}_{2}-\mathrm{C}\left(\mathrm{gCm}^{-2}\right)=\sum_{\mathrm{i}=\text { first }}^{\mathrm{i}=\text { last- }}\left(\frac{\mathrm{D}_{\mathrm{i}}+\mathrm{D}_{\mathrm{i}+1}}{2} \times\left(\mathrm{N}_{\mathrm{i}+1}-\mathrm{N}_{\mathrm{i}}-1\right)+\mathrm{Di}\right)+\mathrm{D}_{\text {last }}
\end{gathered}
$$

where $\mathrm{Di}$ is the $\mathrm{CO}_{2}-\mathrm{C}$ emission on the measurement day $\left(\mathrm{g} \mathrm{C} \mathrm{m}^{-2}\right)$, and $\mathrm{R}_{\mathrm{si}}$ is the soil respiration rate on the measurement day $\left(\mu \mathrm{mol}^{-2} \mathrm{~s}^{-1}\right)$. The molar mass of $\mathrm{CO}_{2}-\mathrm{C}$ is $12 \mathrm{~g}$ $\mathrm{mol}^{-1} ; 3600,24$, and $10^{-6}$ are conversion coefficients, and first and last represent the first and last soil respiration measurements, respectively. $\mathrm{N}_{\mathrm{i}+1}$ minus $\mathrm{Ni}$ and 1 represents the number of days between the first and second measurements.

The SR was measured from 9 am to 11 am and the average value was taken as the soil respiration rate of the day. According to the soil respiration rate of the day, the cumulative soil respiration in the growing season from April to September was calculated using the interpolation method (based on $\mathrm{CO}_{2}, \mathrm{~g} \mathrm{C} \mathrm{m}^{-2}$ ) [44].

SPSS 20.0 software was used to analyze the data. Significant differences were carried out by one-way ANOVA and Tukey test. ANOVA (LSD) were used to test the differences in the SR, distance, soil temperature, and soil moisture in different regions, as well as the differences in the cumulative soil respiration under different tillage and irrigation systems. The linear regression method was used to simulate the relationship between the SR and soil temperature, soil moisture, soil organic carbon, $\mathrm{pH}$, and soil bulk density (the $\mathrm{SR}$, soil temperature, soil moisture, soil organic carbon, $\mathrm{pH}$, and soil bulk density are the monthly average values from April to September 2019). The significance level was set as $p<0.05$. All charts were drawn using origin 2018 software.

\section{Result}

3.1. Differences in Temporal Variation in the SR in the Apple Orchards in Different Areas

The SR in FP and YL in the southern plain area were always higher than that in LC in tableland-gully area, and AS and MZ in the northern hilly and gully area was always lower from April to September $2019(p<0.05)$ (Figure 5a,b). The decrease in the SR between sites corresponded with the decreasing mean annual temperature from FP and $\mathrm{YL}$, to $\mathrm{LC}$, with AS and MZ having the lowest $(p<0.05)$ (Table 1). The SR in all experimental orchards showed a rapid upward trend, with the soil temperature rising in April, and the increased range of SR in FP, YL, and LC was clearly greater than that in MZ and AS, which may be due to their rapid rise in air temperature (Figure 2) and soil temperature (Figure $5 c, d$ ), which accelerated both root and microbial respiration. After that, the SR in FP, YL and LC declined rapidly, whereas in MZ and AS it declined slowly. 


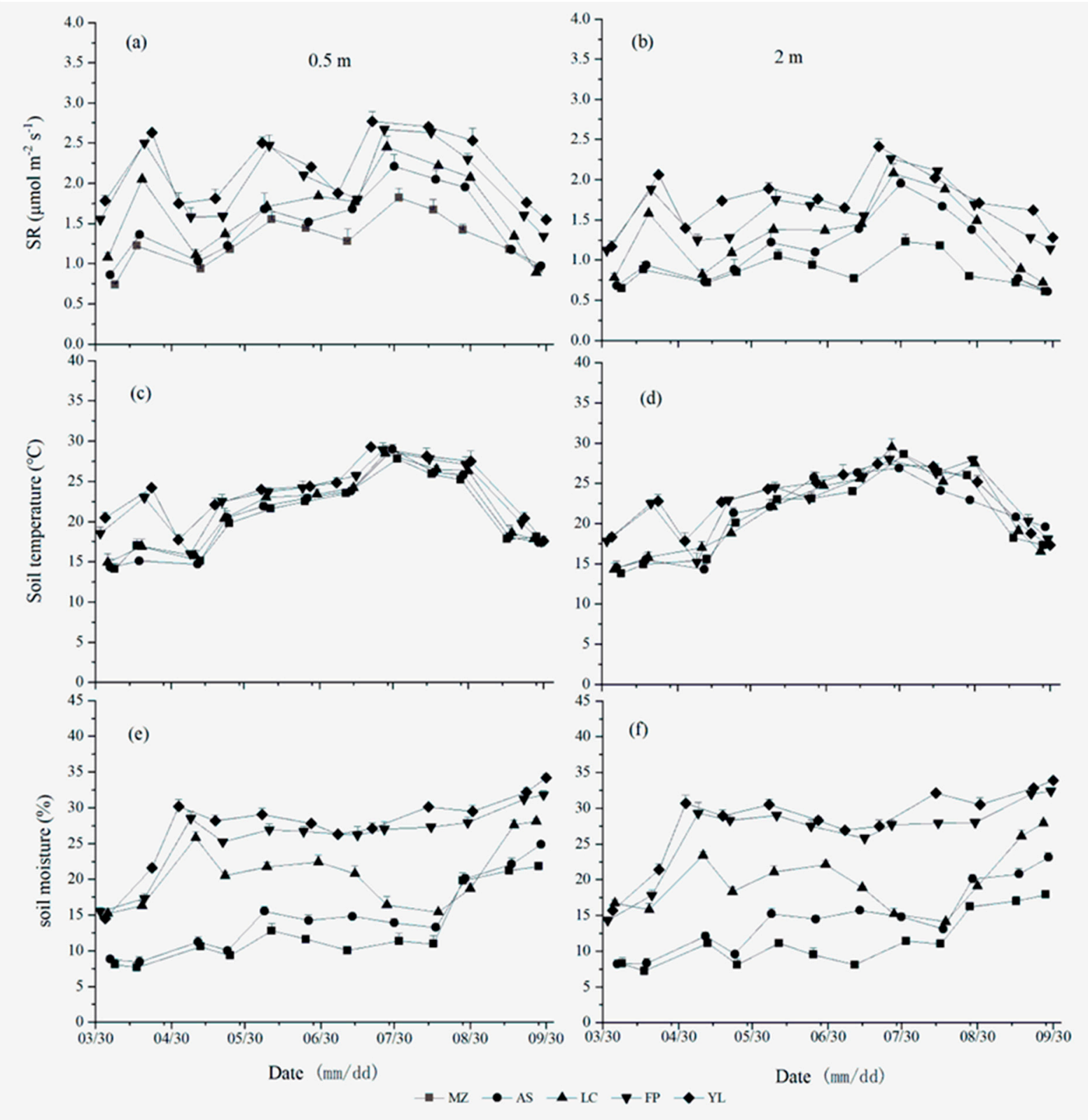

Figure 5. The temporal dynamics of soil respiration (SR) $(\mathbf{a}, \mathbf{b})$, soil temperature $(\mathbf{c}, \mathbf{d})$ and soil moisture $(\mathbf{e}, \mathbf{f})(\mathbf{c})$ in the apple orchards in different areas. The error bars represent the standard errors $(n=9)$.

From the beginning to the end of May, the SR slowly rose with the soil temperature, and, from the beginning of June, the variation in SR was close to the change in soil moisture in all experimental orchards. The SR in all experiment orchards increased sharply from the end of July to the beginning of August, and this is consistent with the peak growth period of apple tree roots. The SR in all experimental orchards was relatively high throughout August, which was related to high rainfall, soil moisture, and temperature at this stage. In September, the SR in all the experimental orchards showed a decreasing trend. This was consistent with the soil temperature although the soil moisture was at a high level (Figure $5 \mathrm{c}-\mathrm{f}$ ). The SR at 0.5 and $2 \mathrm{~m}$ showed similar seasonal changes, and the SR at $0.5 \mathrm{~m}$ was always larger than that at $2 \mathrm{~m}$ from April to September $2019(p<0.05)$. The average SR at $0.5 \mathrm{~m}$ in MZ, AS, LC, FP, and YL was 1.28, 1.48, 1.66, 2.01, and $2.16 \mu \mathrm{mol} \mathrm{m}^{-2} \mathrm{~s}^{-1}$, respectively, which increased by $47.9 \%, 32.9 \%, 28.1 \%, 27.1 \%$, and $24.9 \%$, respectively, compared with the values at $2 \mathrm{~m}$. 


\subsection{Differences in Spatial Variation in the Soil Respiration in the Apple Orchards in Different Areas}

Soil respiration decreased with the distance (from the tree trunk to measuring point) increasing in all experimental orchards, and the SR at $2 \mathrm{~m}$ in MZ, AS, LC, FP, and YL was $0.87,1.11,1.29,1.58$, and $1.73 \mu \mathrm{mol} \mathrm{m}{ }^{-2} \mathrm{~s}^{-1}$, respectively, which were decreased by $32.8 \%, 24.7 \%, 22.2 \%, 21.4 \%$, and $20.2 \%$, respectively, compared with the SR at $0.5 \mathrm{~m}$ (Figure 6d). Soil temperature and moisture did not change with distance from tree in in all the experimental orchards (Figure 6a,b), which indicates that soil temperature and soil moisture are not the primary factors causing spatial variation in SR at the individual tree scale. However, the fine root biomass decreased with increasing distance in all the experimental orchards, and the fine root biomass at $2 \mathrm{~m}$ in MZ, AS, LC, FP, and YL was reduced by $33.02 \%, 33.82 \%, 33.99 \%, 35.82 \%$, and $29.74 \%$ compared with that at $0.5 \mathrm{~m}$, respectively (Figure 6c); this is consistent with the spatial variation in SR. The above results indicated that the fine root biomass was the main controlling factor of the spatial variation in SR at the individual tree scale.


Figure 6. Effect of distance on the variability in the (a) soil temperature, (b) soil moisture, (c) fine root biomass, and (d) soil respiration (SR). Values are the mean for each position $(n=312$, only fine root biomass $n=78$; and the bars are the standard errors of the means). For determination of the distance, see Figure 3.

In the entire study area, the average SR and cumulative soil respiration of apple orchards on the Loess Plateau of Shaanxi Province increased from the north to south $(p<0.05)$. The order was MZ $<\mathrm{AS}<\mathrm{LC}<\mathrm{FP}<\mathrm{YL}$. The SR and cumulative soil respiration in FP and YL in the southern plain area were significantly higher than that in LC in the tableland-gully area, and that in AS and MZ in the northern hilly and gully area $(p<0.05)$. Abiotic factors, such as the soil temperature, soil moisture, and soil organic carbon showed a similar pattern. There was no significant difference in the fine root biomass between different regions, indicating that the spatial difference in the SR and cumulative 
soil respiration in the whole study area was mainly caused by the soil temperature, soil moisture and soil organic carbon (Table 2).

Table 2. Average values of the SR, cumulative soil respiration, soil temperature, soil moisture, fine root biomass and soil organic carbon of orchards in different regions.

\begin{tabular}{|c|c|c|c|c|c|c|}
\hline Regions & $\begin{array}{l}\mathrm{SR}(\mu \mathrm{mol} \\
\left.\mathrm{m}^{-2} \mathbf{s}^{-1}\right)\end{array}$ & $\begin{array}{c}\text { Cumulative Soil } \\
\text { Respiration } \\
\left(\mathrm{g} \mathrm{C} \mathrm{m}^{-2}\right)\end{array}$ & $\begin{array}{c}\text { Soil } \\
\text { Temperature } \\
\left({ }^{\circ} \mathrm{C}\right)\end{array}$ & $\begin{array}{c}\text { Soil Moisture } \\
(\%)\end{array}$ & $\begin{array}{c}\text { Soil Organic } \\
\text { Carbon }\left(\mathrm{g} \mathrm{kg}^{-1}\right)\end{array}$ & $\begin{array}{l}\text { Fine Root } \\
\text { Biomass } \\
\left(\mathrm{g} \mathrm{m}^{-2}\right)\end{array}$ \\
\hline $\mathrm{MZ}$ & $1.14(0.38) \mathrm{C}$ & $205(35) c$ & $20.49(4.58) \mathrm{b}$ & $11.46(4.11) \mathrm{d}$ & $4.18(0.17) \mathrm{d}$ & 174.5 (29) b \\
\hline AS & $1.33(0.44) b$ & $244(28) b c$ & $21.00(4.56) b$ & $14.23(4.88) \mathrm{c}$ & $4.98(0.36) \mathrm{c}$ & $168(30) b$ \\
\hline LC & $1.49(0.47) \mathrm{b}$ & $278(28) b$ & $21.76(4.31) \mathrm{ab}$ & $19.88(4.33) \mathrm{b}$ & $8.50(0.50) b$ & $204.75(37) b$ \\
\hline $\mathrm{FP}$ & $1.80(0.46) \mathrm{a}$ & 338 (39) a & $22.99(3.94) \mathrm{a}$ & $25.99(4.95) \mathrm{a}$ & $10.75(0.37)$ a & $217.5(40) \mathrm{b}$ \\
\hline YL & $1.96(0.43) \mathrm{a}$ & 369 (36) a & $23.41(3.72) \mathrm{a}$ & $27.25(4.98) \mathrm{a}$ & $11.19(0.50) \mathrm{a}$ & $224(25) \mathrm{a}$ \\
\hline
\end{tabular}

Note: Numbers followed by the same letters within a column for a parameter indicate no significant difference between sites with Tukey LSD test at the 0.05 level. Values in parentheses are standard errors. The values of SR, soil temperature, and soil moisture were derived from 12 bimonthly dates from April 2019 to September 2019. The fine root biomass and soil organic carbon were determined monthly from July 2019 to September 2019.

The spatial CV of SR among the five orchards averaged 23.3\% from April to September 2019, and the highest spatial CV among the orchards was observed in April, with a maximum value of $32.8 \%$, The $C V$ value in late September was also larger, whereas the lowest CV was found in late July, with a minimum value of $15.8 \%$ (Figure 7 ).

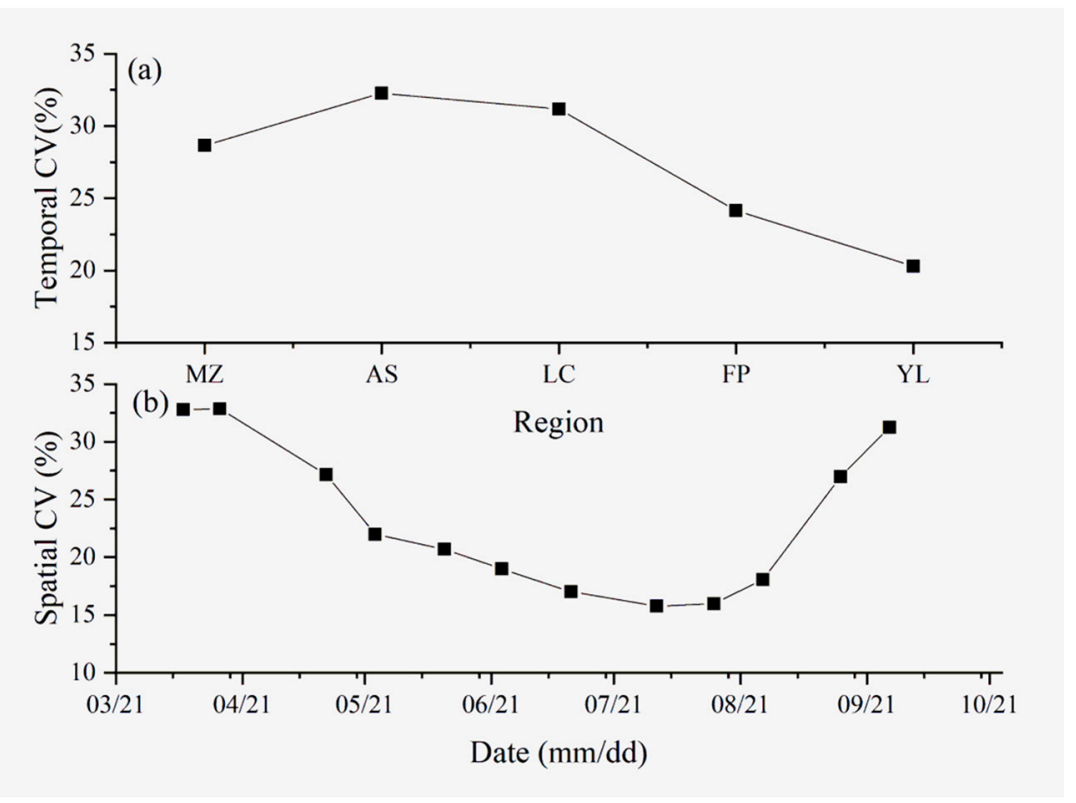

Figure 7. The temporal and spatial coefficient of variation $(\mathrm{CV})$ in the soil respiration. (a) The temporal CV of soil respiration for the five orchards and (b) the spatial CV of the soil respiration among the five orchards during the experimental period.

\subsection{Temporal SR Related to Soil Temperature and Soil Moisture}

There was a positive exponential correlation between the SR and soil temperature at 5 -cm depth $\left(T_{5}\right)$ in all experimental orchards $(p<0.05)$ (Figure 8). The soil temperature explained $60-87 \%$ of the seasonal variation in SR. The regression analysis results for the SR and soil moisture at $5 \mathrm{~cm}$ are shown in Table 3, and the relationship between the SR and soil moisture at the $0-5 \mathrm{~cm}$ depth followed a quadratic function in the same orchards. The regression coefficients in MZ, AS, and LC were higher those that in FP and $\mathrm{YL}$, which showed that the relationship between the SR and soil moisture in MZ, AS, and LC was stronger than that relationship in FP and YL $(p<0.05)$. 



Figure 8. Relationship between the SR and soil temperature at 5-cm depth indifferent regional orchards.

The soil moisture explained $49-56 \%$ of the temporal variation in the SR in AS and MZ in the northern hilly and gully area, and in the tableland-gully area and southern plain area, the soil moisture explained $46-52 \%$ and $31-45 \%$, respectively. Compared with the soil temperature, the correlation of the SR with the soil moisture was weak. By fitting the bivariate equation of the effect of the soil temperature and moisture on soil respiration, the $\mathrm{R}^{2}$ did not increase significantly compared with the $\mathrm{R}^{2}$ fitted by soil temperature alone (Equation (1)) (data not shown). 
Table 3. Relationship between soil respiration $\left(\mu \mathrm{mol} \mathrm{m}^{-2} \mathrm{~s}^{-1}\right)$ and soil moisture (\%) at $0-5 \mathrm{~cm}$ in depth.

\begin{tabular}{|c|c|c|c|c|}
\hline Area & Distance (m) & Functions & $\mathbf{R}^{2}$ & $p$ \\
\hline \multirow{2}{*}{$\mathrm{MZ}$} & 0.5 & $\mathrm{SR}=-0.014 \theta^{2}+0.422 \theta-1.499$ & 0.50 & $<0.05$ \\
\hline & 2 & $\mathrm{SR}=-0.013 \theta^{2}+0.309 \theta-0.839$ & 0.49 & $<0.05$ \\
\hline \multirow{2}{*}{ AS } & 0.5 & $\mathrm{SR}=-0.013 \theta^{2}+0.428 \theta-1.691$ & 0.56 & $<0.05$ \\
\hline & 2 & $\mathrm{SR}=-0.013 \theta^{2}+0.406 \theta-1.732$ & 0.49 & $<0.05$ \\
\hline \multirow{2}{*}{ LC } & 0.5 & $\mathrm{SR}=-0.007 \theta^{2}-0.233 \theta-0.016$ & 0.46 & $=0.06$ \\
\hline & 2 & $\mathrm{SR}=0.002 \theta^{2}-0.170 \theta+3.716$ & 0.52 & $<0.05$ \\
\hline \multirow{2}{*}{ FP } & 0.5 & $\mathrm{SR}=-0.011 \theta^{2}+0.499 \theta-3.256$ & 0.31 & $>0.05$ \\
\hline & 2 & $\mathrm{SR}=-0.009 \theta^{2}+0.437 \theta-3.092$ & 0.44 & $=0.07$ \\
\hline \multirow{2}{*}{ YL } & 0.5 & $\mathrm{SR}=-0.008 \theta^{2}+0.377 \theta-1.982$ & 0.36 & $>0.05$ \\
\hline & 2 & $\mathrm{SR}=-0.008 \theta^{2}+0.413 \theta-3.233$ & 0.45 & $=0.07$ \\
\hline
\end{tabular}

Note: $\mathrm{SR}$ is soil respiration, $\theta$ is the soil moisture, $\mathrm{R}^{2}$ is the determination coefficient, between the $0.5-\mathrm{m}$ - and 2- $\mathrm{m}$-distances treatments (soil respiration measurement points at two distances).

3.4. The Regional Variation in SR Is Related to the Soil Temperature, Soil Moisture, Soil Organic Carbon, $p H$ and Soil Bulk Density

At the regional scale, the main factors affecting the spatial variation in the soil respiration were the soil temperature, soil moisture, soil organic carbon, $\mathrm{pH}$, and soil bulk density. We used linear regression analyses to study the relationships between the spatial variability of SR and some possible driving variables. The results showed that the soil temperature, soil moisture, soil organic carbon and soil bulk density were positively correlated with the $\mathrm{SR}$, whereas the $\mathrm{pH}$ was negatively correlated with the SR on the regional scale (Figure 9). The relationship between the fine root biomass and SR was not significant (data not shown).

\subsection{Effects of Agricultural Management Practices on SR}

Irrigation was significant for soil moisture and SR $(p<0.05)$, but irrigation was not significant for soil temperature in MZ from April 1 to June 30, 2019. The soil moisture at $5 \mathrm{~cm}$ was higher in the irrigated treatment compared with the non-irrigated treatment $(p<0.05)$ (Figure 10e). As expected, we observed a lower soil temperature and higher soil moisture with irrigated treatment on these days when irrigation was done to meet the apple trees water requirements during the drought (Figure 10c,e). Compared with the SDI method, the RII method demonstrated a higher soil temperature and lower soil moisture at the 5 -cm soil layer a few days after irrigation $(p<0.05)$, the soil moisture and temperature of both irrigation methods were close to each other at about ten days after irrigation. The SR was higher in the irrigated treatment compared with the non-irrigated treatment $(p<0.05)$ (Figure 10a). The SR of SDI was higher than that of RII a few days after irrigation, and was lower than that of RII about ten days after irrigation $(p<0.05)$. This may be due to the fact that the soil moisture of the RII sub-layer is higher than with SDI because of the infiltration and evaporation of soil water, which promotes root respiration.

On the first day of evaluation, in comparing NT $\left(0.68 \mu \mathrm{mol} \mathrm{m}^{-2} \mathrm{~s}^{-1}\right)$, ST $(0.73 \mu \mathrm{mol}$ $\left.\mathrm{m}^{-2} \mathrm{~s}^{-1}\right)$, and DT $\left(0.88 \mu \mathrm{mol} \mathrm{m} \mathrm{m}^{-2} \mathrm{~s}^{-1}\right)$, the effect of soil tillage on SR is apparent $(p<0.05)$. After tillage, and frequent, alternated soil drying and wetting, soil organic matter decomposition accelerates. Therefore, the SR under ST increased by $7.35 \%$, and the SR under DT increased by $29 \%$. (Figure 10b). During the entire experiment, changes in the SR caused by precipitation events were observed. The precipitation of $42 \mathrm{~mm}$ on the 24th day changed the SR to 1.18-1.55 $\mu \mathrm{mol} \mathrm{m}{ }^{-2} \mathrm{~s}^{-1}$ under ST (the 25th day) and 1.56-1.67 $\mu \mathrm{mol} \mathrm{m} \mathrm{m}^{-2} \mathrm{~s}^{-1}$ under DT $(p<0.05)$. The increase in SR under ST and DT may be related to the increase in soil moisture in the same period (Figure 10f). However, under GC conditions, the presence of mulch on the soil surface reduced the impact of precipitation on SR (Figure 10b), as the mulch forms a physical barrier to the sudden entry of moisture. 

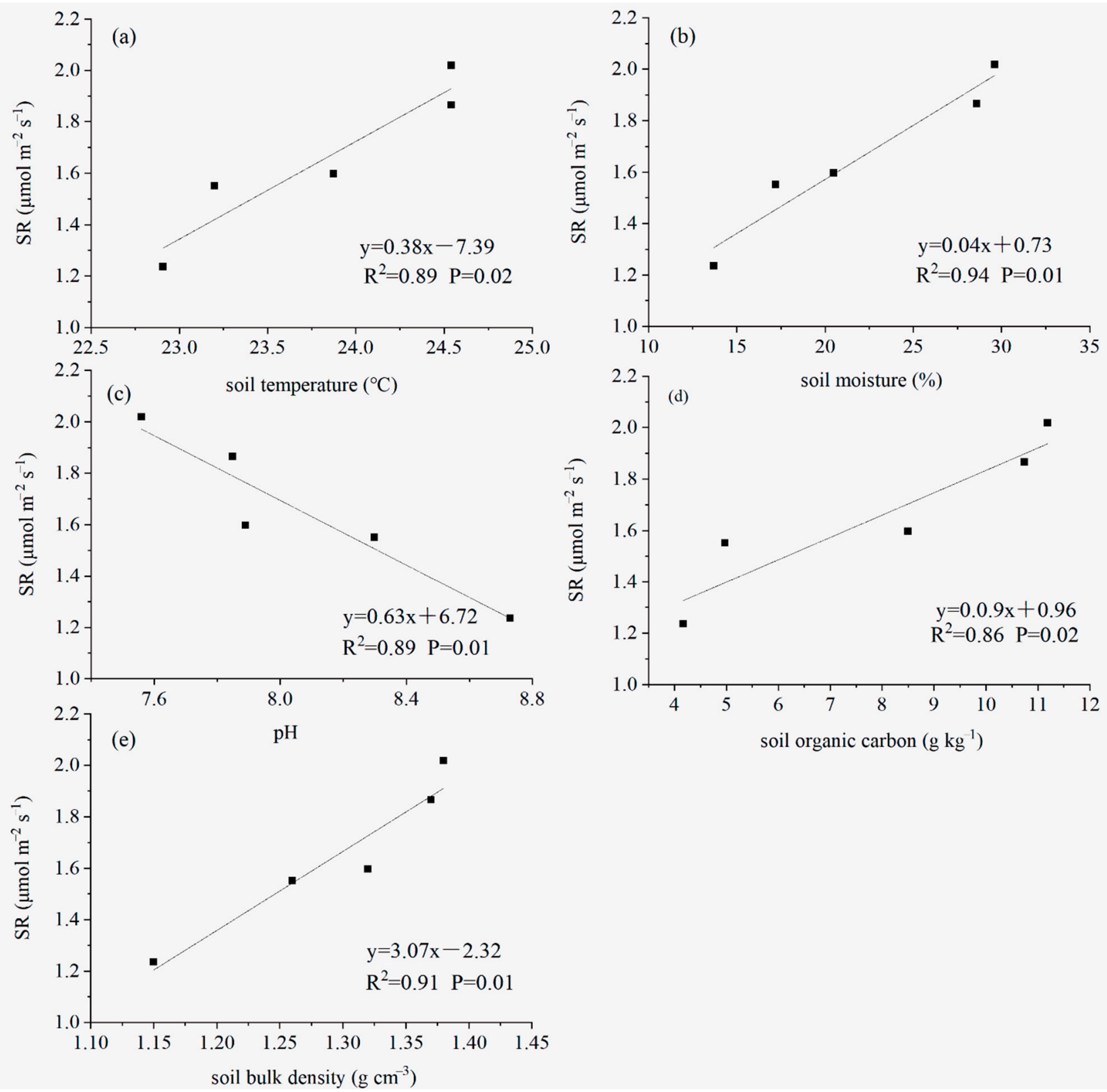

Figure 9. Relationships between the SR and soil temperature at a 5-cm depth (a), soil moisture at a 5-cm depth (b), soil organic carbon (c), $\mathrm{pH}(\mathbf{d})$, and soil bulk density (e), across the five orchards. The values for the SR, soil temperature, soil moisture, soil organic carbon, $\mathrm{pH}$, and soil bulk density were monthly averaged values from July to September 2019 . $\mathrm{R}^{2}$ was the determination coefficient. The significance level was set as $p<0.05$.

There were large differences in the cumulative soil respiration under different agricultural management practices $(p<0.05)$ (Figure 11). In semi-arid orchards, irrigation significantly increased the cumulative soil respiration due to an improved soil moisture contents $(p<0.05)$. The water treatment significantly affected the cumulative growing season SR $(p<0.05)$. RII $\left(118 \mathrm{~g} \mathrm{C} \mathrm{m}^{-2}\right)$ and SDI $\left(116 \mathrm{~g} \mathrm{C} \mathrm{m}^{-2}\right)$ increased the cumulative soil respiration by $38.82 \%$ and $36.47 \%$, respectively $(p<0.05)$, while the cumulative soil respiration under SDI and RII showed little difference. In addition, compared with NT under different tillage methods, ST, DT, and GC increased by $14 \%, 36 \%$ and $57 \%$, respectively $(p<0.05)$. There was no significant difference in the cumulative soil respiration between NT and ST. However, GC had the largest cumulative soil respiration compared to other tillage methods $(p<0.05)$. 

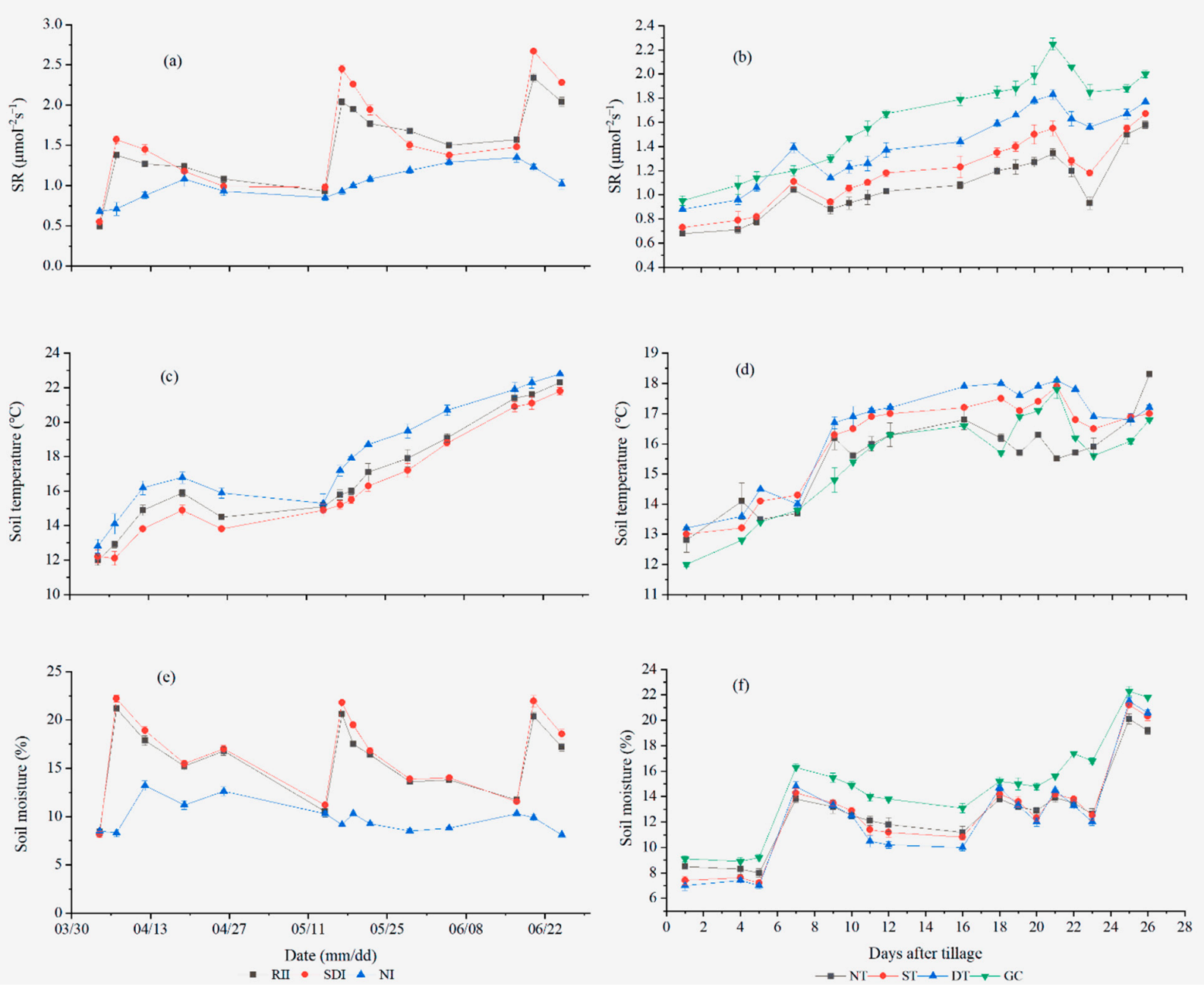

Figure 10. The average values for root injection irrigation (RII), traditional surface drip irrigation (SDI), non-irrigated (NI), no-tillage (NT), shallow tillage (ST), deep tillage (DT), and green cover (GC). (a,b) SR $\left(\mu \mathrm{mol} \mathrm{m}^{-2} \mathrm{~s}^{-1}\right)$, (c,d) soil temperature $\left({ }^{\circ} \mathrm{C}\right)$, and $(\mathbf{e}, \mathbf{f})$ soil moisture $(\%)$.

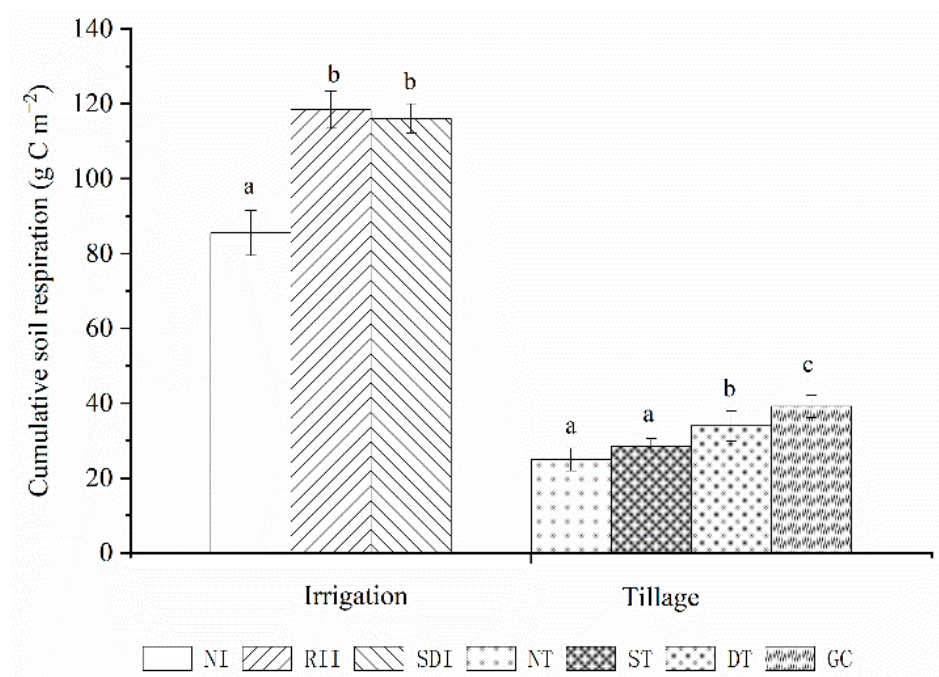

Figure 11. The mean cumulative soil respiration for root injection irrigation (RII), traditional surface drip irrigation (SDI), non-irrigated (NI), green cover (GC), deep tillage (DT), shallow tillage (ST), and no-tillage (NT). The same letters indicate no significant difference between treatments with Tukey LSD test at the 0.05 level. 


\section{Discussion}

\subsection{Temporal Variability of $S R$}

The seasonal variation in SR is consistent with the soil temperature variation in the five orchards in the different region of the Chinese Loess Plateau, which is consistent with other research results $[16,45]$. High SR occurs from July to September, due to the high precipitation and suitable temperature, providing sufficient water and heat for root system and microbial activities. In this study, the coefficient of variation for SR was relatively large $(20-32 \%)$, as well as the choice of the appropriate time point is very important for estimation of the SR. Soil temperature regulates SR, mainly by affecting the role of the root system and the decomposition rate of organic matter; thus, it is often used to explain the majority of SR $[22,28]$. The exponential model can explain the change in SR with soil temperature in different regions of this study. Soil temperature alone accounted for $59-87 \%$ of the seasonal variation in SR, indicating that soil temperature was the main driving force of the variation in SR in each experimental orchard, which is consistent with the results of other studies $[23,46]$. In our study, the $\mathrm{Q}_{10}$ values ranged from 1.55 to 1.88 across the five orchards, with an average of 1.67, which was consistent with the reports in other regions. For example, Wang et al. [22] worked in typical orchards in the full fruit period in Loess Plateau area, and calculated the $\mathrm{Q}_{10}$ values of orchards in 2012, ranging from 1.38 to 1.79. Zanotelli et al. [47] reported that the $Q_{10}$ values in 2011 ranged from 1.64 to 1.72 , with an average of 1.68 in apple orchards. When Raich and Schlesinger [48] conducted a comprehensive analysis on the soil respiration of different ecosystems at the global scale, they found that the $\mathrm{Q}_{10}$ value was 2.4 , as the median value, which varied from 1.3 to 3.3 .

In addition to the soil temperature, soil moisture is another factor which was extensively studied at the ecosystem level, affecting the temporal variability in SR [49,50]. The relationship between SR and soil moisture was found to be a quadratic polynomial function (Table 3). We found that the response relationship of the SR to soil moisture was different in different regions, and the relationships between SR and SM in MZ, AS, and LC were stronger than those in FP and YL. This may be due to the soil experiencing seasonal drought, which may limit the microbial activity in certain months. At the same time, the response of root respiration to seasonal changes in SR may be stronger than in FP and YL. However, compared with the relationship between the SR and soil temperature, the relationship between the SR and soil moisture is relatively weak, which is consistent with the results reported in other regions [15,51]. Regression models based on the soil temperature and soil moisture did not explain the SR more than those based on soil temperature alone (data not shown). Previous studies have shown that fitting the composite relationship of SR, soil temperature and soil moisture could improve the accuracy of soil respiration prediction [52-54]. In this study, the interaction of soil temperature and soil moisture had little effect on the temporal variability of SR in these orchards. In addition, the microbial population, fine root biomass, organic matter input, and distribution pattern of photosynthetic products may have a strong impact on the seasonal variation in SR in the study area.

\subsection{Spatial Variability of $S R$}

The SR was high from July to September, due to high temperature and high precipitation, which allowed for high root and soil microbial activities. The soil temperature and soil moisture have an important impact on the spatial variability in the SR under a single tree [55-57]. In this study, the average soil temperature and soil moisture did not change significantly under a single tree in all experimental orchards (Figure 6a,b), which indicated that abiotic factors (soil temperature and soil moisture) were not the main factors affecting the spatial variation at the single-tree scale. Similar results were observed in temperate beech forests in Germany [37], Mediterranean oak forests in central Italy [12], larch plantations in Hokkaido in Japan [58] and Mediterranean mixed forests in Catalonia [59]. The SR value decreased with an increase in the distance from the trunk $[4,60]$, and the change in 
the SR value was consistent with that of the fine root biomass of each experimental fruit tree $[11,13]$.

On the regional scale, the highest spatial CV among the orchards were observed in April, with a maximum value of $32.8 \%$ (Figure 7 ). This is mainly due to the slow rise in temperature in the north, the dry climate, and the temperature and soil moisture in the north being significantly lower than in the south. The CV value in late September was also larger; this is mainly caused by the rapid decrease in air temperature in the north of China, and the difference in soil moisture in different regions being smaller. The CV value from July to August was lower; this is due to small differences in temperature and moisture in different regions. The factors leading to regional variation in SR are complex. The soil temperature and soil moisture had significant effects on the regional variation in SR (Figure 9), which usually consisted of autotrophic and heterotrophic respiration [61]. Compared with other orchards, MZ orchards had the smallest soil respiration. One reason for this is that the low soil temperature and soil moisture are not conducive to root growth, reducing the soil autotrophic respiration. Another reason for this is that the content of the soil organic carbon in MZ is very low; therefore, it cannot provide much substrate for soil microorganisms, thus inhibiting the soil microbial activities and reducing soil heterotrophic respiration. On the regional scale, soil temperature, soil moisture and soil organic carbon were the main factors affecting the regional difference in soil respiration. These factors were all positively correlated with soil respiration, which is consistent with other studies [62-64]. Soil pH is also a major factor affecting soil respiration [32], and some studies have shown that soil respiration was negatively correlated with $\mathrm{pH}$ [46] or, conversely, positive correlated [65]. Our results showed that the SR was negatively correlated with $\mathrm{pH}$ in the Loess Plateau of Chinese Shaanxi Province, which may be related to the high $\mathrm{pH}$ (from 7.5 to 8.7) of the soil in this area, and plant root growth and soil microbial activity decreased with an increase in soil $\mathrm{pH}$ value. In addition, soil bulk density is also a factor affecting soil respiration. The lower the soil bulk density is, the higher the soil porosity is, and the higher the soil oxygen availability is, which is conducive to the activity of microorganisms and leads to an increase in SR [36,46]. However, our results showed that the soil bulk density was positively correlated with the SR on the regional scale, which indicated that the effect of soil bulk density on SR was covered by hydrothermal factors, biological factors and other factors.

In this study, we found that the $Q_{10}$ values also exhibited spatial variability on the regional scale. From north to south, the $\mathrm{Q}_{10}$ values of orchards in the entire experimental area had a decreasing trend (Table 4$)$, and the $Q_{10}$ value of YL was the smallest $(p<0.05)$. On the one hand, the soil temperature of $Y L$ was higher, which can affect the community structure and biomass of soil organisms, and can regulate the supply of substrate, thus significantly affecting the $Q_{10}$. The $Q_{10}$ values under high-temperature conditions were smaller than under low temperatures [66]. On the other hand, YL has abundant rainfall $(649.5 \mathrm{~mm})$ and sufficient soil moisture $(27.25 \%)$ during the whole determination period (Figures 2 and 5). When the soil moisture is too high, the soil permeability will be reduced, and the $\mathrm{O}_{2}$ content in the soil will be reduced, thereby inhibiting the respiration of soil microorganisms and plant roots; thus, the respiration of soil microbes and plant roots was inhibited, and the $\mathrm{Q}_{10}$ was reduced (1.55-1.6). Some studies have shown that $\mathrm{Q}_{10}$ had a negative quadratic polynomial relationship with soil moisture $[67,68]$. Before the soil moisture reaches the threshold value, the $\mathrm{Q}_{10}$ increases with an increase in water content, and then decreases gradually after reaching the threshold value $[27,69]$.

The $Q_{10}$ values at 0.5 and $2 \mathrm{~m}$ were 1.88 and 1.82 , respectively, in $M Z$, while the $Q_{10}$ values at 0.5 and $2 \mathrm{~m}$ were 1.60 and 1.55, respectively, in YL (Table 4). The regression analyses indicated that distance did not significantly affect $\alpha$; this did not alter the temperature sensitivity $\beta$. The fine root biomass at $0.5 \mathrm{~m}$ was significantly higher than that $2 \mathrm{~m}(p<0.05)$; however, these two sites had very close soil temperatures and similar soil moisture, which indicated that the effect of the fine root biomass on $\mathrm{Q}_{10}$ was covered by soil temperature and soil moisture. Soil temperature and moisture are also important factors 
for tree scale $Q_{10}$ patterns. In addition, the uncertainty of $Q_{10}$ is affected by a variety of factors and the interactions among them, including the measured depth of soil temperature, spatiotemporal scale, fertilization measures, and the difference in the different components of $\mathrm{Q}_{10}[35,70]$.

Table 4. The relationship between the soil temperature $\left({ }^{\circ} \mathrm{C}\right)$ and SR $\left(\mu \mathrm{molm}^{-2} \mathrm{~s}^{-1}\right)$.

\begin{tabular}{|c|c|c|c|c|c|c|c|c|}
\hline Area & Distance/m & $\alpha$ & $\beta$ & $\mathbf{t}_{\alpha}$ & $\mathbf{t}_{\beta}$ & $\mathrm{R}^{2}$ & $p$ & $\mathrm{Q}_{10}$ \\
\hline \multirow{2}{*}{$\mathrm{MZ}$} & 0.5 & $0.318 \pm 0.052$ & $0.063 \pm 0.008$ & -2.419 & 0.489 & 0.82 & $<0.05$ & 1.88 \\
\hline & 2 & $0.411 \pm 0.054$ & $0.060 \pm 0.007$ & & & 0.61 & $<0.05$ & 1.82 \\
\hline \multirow{2}{*}{ AS } & 0.5 & $0.408 \pm 0.072$ & $0.059 \pm 0.008$ & 0.879 & 0.142 & 0.87 & $<0.05$ & 1.80 \\
\hline & 2 & $0.312 \pm 0.175$ & $0.057 \pm 0.023$ & & & 0.60 & $<0.05$ & 1.77 \\
\hline \multirow{2}{*}{ LC } & 0.5 & $0.482 \pm 0.144$ & $0.056 \pm 0.012$ & 0.726 & 0.294 & 0.63 & $<0.05$ & 1.75 \\
\hline & 2 & $0.401 \pm 0.129$ & $0.053 \pm 0.013$ & & & 0.62 & $<0.05$ & 1.70 \\
\hline \multirow{2}{*}{$\mathrm{FP}$} & 0.5 & $0.651 \pm 0.120$ & $0.048 \pm 0.008$ & 1.230 & 0.120 & 0.68 & $<0.05$ & 1.62 \\
\hline & 2 & $0.533 \pm 0.115$ & $0.047 \pm 0.012$ & & & 0.66 & $<0.05$ & 1.60 \\
\hline \multirow{2}{*}{ YL } & 0.5 & $0701 \pm 0.147$ & $0.047 \pm 0.008$ & 0.561 & 0.382 & 0.78 & $<0.05$ & 1.60 \\
\hline & 2 & $0.629 \pm 0.167$ & $0.044 \pm 0.011$ & & & 0.66 & $<0.05$ & 1.55 \\
\hline
\end{tabular}

Note: $\alpha$ and $\beta$ are two coefficients in the regression line $S R=\alpha e^{\beta T}$, where $S R$ is the soil respiration, $T_{5}$ is the soil temperature, $R^{2}$ is the determination coefficient, $\mathbf{t}_{\alpha}$ and $\mathbf{t}_{\beta}$ are the Student's $t$-values for testing statistical significance in the coefficient a and $b$ values, respectively, between the $0.5-\mathrm{m}$ - and 2 -m-distances treatments.

\subsection{SR under Different Soil Management}

Compared with no irrigation, the soil temperature under irrigation was lower and the soil moisture was higher. Increasing the moisture content on the soil surface may reduce the soil temperature, as the temperature change in moist soil is slower than that in dry soil $[25,71]$. The soil moisture under irrigation was significantly higher than that under no irrigation $(p<0.05)$, and the increase in soil water content, rather than the difference in soil temperature (Figure 10), may have increased the SR from irrigation during these periods. In arid soils, SR increases due to increased carbon mineralization and root respiration [72-74]. Dry-land irrigation may increase the root respiration and microbial activity, thereby increasing the SR. In this study, compared with the unirrigated treatment, the cumulative soil respiration under SDI and RII increased by $35.77 \%$ and $38.54 \%$, respectively, during the entire measurement period (Figure 11). This indicates that irrigation increased the cumulative soil respiration, and irrigation methods (such as the RII method) that can maintain a higher soil moisture content for a longer period of time can further increase the soil respiration in arid and semi-arid areas. Different tillage methods have a great influence on SR $[8,75,76]$. In this study, compared with NT, the cumulative soil respiration was significantly increased under all tillage treatments except shallow tillage. Tillage can increase soil heterotrophic respiration by destabilizing the carbon stored in soil aggregates and through an increase in soil microbial activity, which enhances carbon mineralization $[77,78]$.

\section{Conclusions}

In the Loess Plateau of Chinese Shaanxi Province, the SR in different areas showed clear seasonal variation with the change in temperature, as they were controlled by soil temperature and soil moisture. The SR and cumulative soil respiration of apple orchards decreased gradually with increasing latitude. On the regional scale, the soil temperature, soil moisture, soil organic carbon, and soil bulk density were positively correlated with the SR, while $\mathrm{pH}$ was negatively correlated with the SR. On a single-tree scale, the SR decreased with increasing distance from the tree trunk, and the fine root biomass was an important factor in the spatial variation in the SR. In semi-arid apple orchards, soil tillage and irrigation increased the SR. Agricultural practices cannot be ignored in the study of temporal and spatial variations in SR. 
Author Contributions: Conceptualization, T.H.; methodology, T.H. and Y.W.; software, T.H. and F.G.; validation, T.H. and Y.W.; formal analysis, T.H.; investigation, T.H., X.W. and Q.J.; resources, E.W. and J.H.; data curation, T.H.; writing-original draft preparation, T.H.; writing-review and editing, T.H.; visualization, T.H. and F.G.; supervision, F.G.; project administration, Y.W.; funding acquisition, Y.W. All authors have read and agreed to the published version of the manuscript.

Funding: Contract/grant sponsor: National Natural Science Foundation of China; contract/grant number: 41571218, 41401613. Contract/grant sponsor: Science-Technology Innovation Project of Shaanxi; contract/grant number: 2021NY-204.

Institutional Review Board Statement: Not applicable.

Informed Consent Statement: Not applicable.

Data Availability Statement: Data sharing not applicable.

Acknowledgments: The authors gratefully acknowledge Rui Wang, Jialin Jin, Zhuling Fang and Guodong Hou for useful discussions and consultations.

Conflicts of Interest: The authors declare no conflict of interest.

\section{References}

1. Jiang, J.; Guo, S.; Zhang, Y.; Liu, Q.; Wang, R.; Wang, Z.; Li, N.; Li, R. Changes in temperature sensitivity of soil respiration in the phases of a three-year crop rotation system. Soil Tillage Res. 2015, 150, 139-146. [CrossRef]

2. Adachi, M.; Ito, A.; Yonemura, S.; Takeuchi, W. Estimation of global soil respiration by accounting for land-use changes derived from remote sensing data. J. Environ. Manag. 2017, 200, 97-104. [CrossRef]

3. Zeng, X.; Song, Y.; Zhang, W.; He, S. Spatio-temporal Variation of Soil Respiration and Its Driving Factors in Semi-arid Regions of North China. Chin. Geogr. Sci. 2018, 28, 12-24. [CrossRef]

4. Tang, J.; Baldocchi, D.D. Spatial-temporal variation in soil respiration in an oak-grass savanna ecosystem in California and its partitioning into autotrophic and heterotrophic components. Biogeochemistry 2005, 73, 183-207. [CrossRef]

5. Ngao, J.; Epron, D.; Delpierre, N.; Bréda, N.; Granier, A.; Longdoz, B. Spatial variability of soil $\mathrm{CO}_{2}$ efflux linked to soil parameters and ecosystem characteristics in a temperate beech forest. Agric. For. Meteorol. 2012, 154-155, 136-146. [CrossRef]

6. Zhou, X.-G.; Zhang, Y.-J.; Nan, Y.-F.; Liu, Q.-F.; Guo, S.-L. Differences in soil respiration between cropland and grassland ecosystems and factors influencing soil respiration on the Loess Plateau. Environ. Sci. 2013, 34, 1026-1033.

7. Gong, J.; Xu, S.; Wang, Y.; Luo, Q.; Liu, M.; Zhang, W. Effect of irrigation on the soil respiration of constructed grasslands in Inner Mongolia, China. Plant Soil 2015, 395, 159-172. [CrossRef]

8. Abido, W.; Hadházy, Á.; Henzsel, I. Effect of tillage method on carbon-dioxide emission andsoil properties under two soil surface levels. Acta Ecol. Sin. 2020, 40, 210-213. [CrossRef]

9. Wang, R.; Guo, S.; Jiang, J.; Wu, D.; Li, N.; Zhang, Y.; Liu, Q.; Li, R.; Wang, Z.; Sun, Q.; et al. Tree-scale spatial variation of soil respiration and its influence factors in apple orchard in Loess Plateau. Nutr. Cycl. Agroecosyst. 2015, 102, 285-297. [CrossRef]

10. María, M.G.R.; Gregorio, E.; Bernardo, B.M.G.; Pedro, A.N.; Alain, B. Spatial variability of soil $\mathrm{CO}_{2}$ efflux in drip-irrigated old and young citrus orchards and its dependence on biotic and abiotic factors. Geoderma 2017, 294, 29-37. [CrossRef]

11. González-Real, M.M.; Martin-Gorriz, B.; Egea, G.; Nortes, P.A.; Baille, A. Characterization and modelling of soil $\mathrm{CO}_{2}$ efflux in old and young irrigated citrus orchards. Catena 2018, 162, 376-385. [CrossRef]

12. Tedeschi, V.; Rey, A.; Manca, G.; Valentini, R.; Jarvis, P.G.; Borghetti, M. Soil respiration in a Mediterranean oak forest at different developmental stages after copping. Glob. Chang. Biol. 2006, 12, 110-121. [CrossRef]

13. Ceccon, C.; Panzacchi, P.; Scandellari, F.; Prandi, L.; Ventura, M.; Russo, B.; Millard, P.; Tagliavini, M. Spatial and temporal effects of soil temperature and moisture and the relation to fine root density on root and soil respiration in a mature apple orchard. Plant Soil 2011, 342, 195-206. [CrossRef]

14. Luo, Y.Q.; Zhou, X.H. Soil Respiration and the Environment; Academic Press: London, UK, 2006; pp. $257-305$.

15. Wang, C.; Huang, R.; Yang, Z.-J.; Liu, Q.; Chen, G.-S.; Wan, X.-H. Dynamic changes of soil respiration in Citrus reticulata and Castanea henryi orchards in Wanmulin Nature Reserve, Fujian Province of East China. Chin. J. Appl. Ecol. 2012, 23, 1469-1475.

16. Yan, J.-X.; Hao, Z.; Jing, X.-K.; Li, H.-J. Interannual Variations of Soil Respiration and Its Temperature Sensitivity in an Orchard in Jinci Region of Taiyuan City. Environ. Sci. 2016, 37, 3625-3633.

17. Scandellari, F.; Zanotelli, D.; Ceccon, C.; Bolognesi, M.; Montagnani, L.; Cassol, P.; Melo, G.; Tagliavini, M. Enhancing prediction accuracy of soil respiration in an apple orchard by integrating photosynthetic activity into a temperature-related model. Eur. J. Soil Biol. 2015, 70, 77-87. [CrossRef]

18. Chen, Q.S.; Li, L.H.; Han, X.G.; Yan, Z.D.; Wang, Y.F.; Zhang, Y.; Xiong, X.G.; Chen, S.P.; Zhang, L.X.; Gao, Y.Z.; et al. Temperature sensitivity of soil respiration in relation to soil moisture in 11 communities of typical temperate steppe in Inner Mongolia. Acta Ecol. Sin. 2004, 24, 831-836. [CrossRef] 
19. Millikin, C.S.; Bledsoe, C.S. Biomass and distribution of fine and coarse roots from blue oak (Quercus douglasii) trees in the northern Sierra Nevada foothills of California. Plant Soil 1999, 214, 27-38. [CrossRef]

20. Gan, Z.-T.; Zhou, Z.-C.; Liu, W.-Z. Vertical Distribution and Seasonal Dynamics of Fine Root Parameters for Apple Trees of Different Ages on the Loess Plateau of China. Agric. Sci. China 2010, 9, 46-55. [CrossRef]

21. Wang, H.; Liu, S.; Wang, J.; Shi, Z.; Lu, L.; Zeng, J.; Ming, A.; Tang, J.; Yu, H. Effects of tree species mixture on soil organic carbon stocks and greenhouse gas fluxes in subtropical plantations in China. For. Ecol. Manag. 2013, 300, 4-13. [CrossRef]

22. Wang, R.; Guo, S.-L.; Liu, Q.-F.; Zhang, Y.-J.; Jiang, J.-S.; Guo, H.-M.; Li, R.-J. Variation characteristic in soil respiration of apple orchard and its biotic and abiotic influencing factors. Environ. Sci. 2014, 35, 1915-1921.

23. Sheng, H.; Yang, Y.; Yang, Z.; Chen, G.; Xie, J.; Guo, J.; Zou, S. The dynamic response of soil respiration to land-use changes in subtropical China. Glob. Chang. Biol. 2010, 16, 1107-1121. [CrossRef]

24. Wiseman, P.; Seiler, J.R. Soil $\mathrm{CO}_{2}$ efflux across four age classes of plantation loblolly pine (Pinus taeda L.) on the Virginia Piedmont. For. Ecol. Manag. 2004, 192, 297-311. [CrossRef]

25. Sainju, U.M.; Jabro, J.D.; Stevens, W.B. Soil Carbon Dioxide Emission and Carbon Content as Affected by Irrigation, Tillage, Cropping System, and Nitrogen Fertilization. J. Environ. Qual. 2008, 37, 98-106. [CrossRef] [PubMed]

26. Eichstein, M.R.; Ubke, J.E.S.; Angeli, A.C.; Tenhunen, J.D. Does the temperature sensitivity of decomposition of soil organic matter depend upon water content, soil horizon, or incubation time? Glob. Chang. Biol. 2005, 11, 1754-1767. [CrossRef]

27. Peng, S.; Piao, S.; Wang, T.; Sun, J.; Shen, Z. Temperature sensitivity of soil respiration in different ecosystems in China. Soil Biol. Biochem. 2009, 41, 1008-1014. [CrossRef]

28. Lavigne, M.B.; Boutin, R.; Foster, R.J.; Goodine, G.; Bernier, P.Y.; Robitaille, G. Soil respiration responses to temperature are controlled more by roots than by decomposition in balsam fir ecosystems. Can. J. For. Res. 2003, 33, 1744-1753. [CrossRef]

29. Zheng, Z.-M.; Yu, G.-R.; Fu, Y.-L.; Wang, Y.-S.; Sun, X.-M.; Wang, Y.-H. Temperature sensitivity of soil respiration is affected by prevailing climatic conditions and soil organic carbon content: A trans-China based case study. Soil Biol. Biochem. 2009, 41, 1531-1540. [CrossRef]

30. Chen, S.; Huang, Y.; Zou, J.; Shen, Q.; Hu, Z.; Qin, Y.; Chen, H.; Pan, G. Modeling interannual variability of global soil respiration from climate and soil properties. Agric. For. Meteorol. 2010, 150, 590-605. [CrossRef]

31. Shi, P.; Qin, Y.; Liu, Q.; Zhu, T.; Li, Z.; Li, P.; Ren, Z.; Liu, Y.; Wang, F. Soil respiration and response of carbon source changes to vegetation restoration in the Loess Plateau, China. Sci. Total. Environ. 2020, 707, 135507. [CrossRef]

32. Yang, J.-F.; Yang, X.-N.; Wang, J.-H.; Duan, Y.-M.; Qi, X.-N.; Zhang, L.-S. Characteristics of $\mathrm{CO}_{2}$ Flux in a Mature Apple (Malus demestica) Orchard Ecosystem on the Loess Plateau. Environ. Sci. 2018, 39, 2339-2350.

33. Zhang, H.; Huang, Y.-M.; Qi, J.-H.; An, S.-S. Effects of temperature and moisture on soil $\mathrm{CO}_{2}$ release potential under three typical land use types in the hill-gully area of the Loess Plateau. Chin. J. Eco-Agric. 2011, 19, 731-737. [CrossRef]

34. Zhang, Y.; Guo, S.; Liu, Q.; Jiang, J.; Wang, R.; Li, N. Responses of soil respiration to land use conversions in degraded ecosystem of the semi-arid Loess Plateau. Ecol. Eng. 2015, 74, 196-205. [CrossRef]

35. Wang, R.; Sun, Q.; Wang, Y.; Zheng, W.; Yao, L.; Hu, Y.; Guo, S. Contrasting responses of soil respiration and temperature sensitivity to land use types: Cropland vs. apple orchard on the Chinese Loess Plateau. Sci. Total Environ. 2018, 621, 425-433. [CrossRef]

36. Chen, Q.; Wang, Q.; Han, X.; Wan, S.; Li, L. Temporal and spatial variability and controls of soil respiration in a temperate steppe in northern China. Glob. Biogeochem. Cycles 2010, 24. [CrossRef]

37. Buchmann, N. Biotic and abiotic factors controlling soil respiration rates in Picea abies stands. Soil Biol. Biochem. 2000, 32, 1625-1635. [CrossRef]

38. Chen, G.S.; Yang, Y.S.; Lü, P.P.; Zhang, Y.P.; Qian, X.L. Regional patterns of soil respiration in China's forests. Acta Ecol. Sin. 2008, 28, 1748-1760. [CrossRef]

39. Iqbal, J.; Hu, R.G.; Du, L.J.; Lu, L.; Lin, S.; Chen, T.; Ruan, L.L. Differences in soil $\mathrm{CO}_{2}$ flux between different land use types in mid-subtropical China. Soil Biol. Biochem. 2008, 40, 2324-2333. [CrossRef]

40. Zhao, G.D.; Wang, B.; Yang, J.; Zhang, Z.J. LI-8100 Automated Soil CO $\mathrm{CO}_{2}$ Flux System and Its Application. Meteorol. Sci. Technol. 2005, 33, 363-366. [CrossRef]

41. Lu, R.K. Analytical Methods for Soil Agrochemistry; Chinese Agricultural Science and Technology Publishing House: Beijing, China, 2000.

42. Liu, G.S. Soil Physical and Chemical Analysis and Profile Description; China Standard Press: Beijing, China, 1996.

43. Wang, Y.; Zhang, L.; Mu, Y.; Liu, W.; Guo, F.; Chang, T. Effect of a root-zone injection irrigation method on water productivity and apple production in a semi-arid region in north-western China. Irrig. Drain. 2019, 69, 74-85. [CrossRef]

44. Tian, X.-Y.; Tu, L.-H.; Hu, T.-X.; Zhang, J.; He, Y.-Y.; Xiao, Y.-L. Characteristics of soil respiration components and their temperature sensitivity in a Pleioblastus amarus plantation in rainy area of West China. Chin. J. Appl. Ecol. 2012, 23, 293-300. [CrossRef]

45. Gnanamoorthy, P.; Selvam, V.; Ramasubramanian, R.; Nagarajan, R.; Chakraborty, S.; Burman, P.K.D.; Karipot, A. Diurnal and seasonal patterns of soil $\mathrm{CO}_{2}$ efflux from the Pichavaram mangroves, India. Environ. Monit. Assess. 2019, 191, 258. [CrossRef]

46. Luo, J.; Chen, Y.; Wu, Y.; Shi, P.; She, J.; Zhou, P. Temporal-Spatial Variation and Controls of Soil Respiration in Different Primary Succession Stages on Glacier Forehead in Gongga Mountain, China. PLoS ONE 2012, 7, e42354. [CrossRef]

47. Raich, J.W.; Schlesinger, W.H. The global carbon dioxide flux in soil respiration and its relationship to vegetation and climate. Tellus B Chem. Phys. Meteorol. 1992, 44, 81-99. [CrossRef] 
48. Zanotelli, D.; Montagnani, L.; Manca, G.; Scandellari, F.; Tagliavini, M. Net ecosystem carbon balance of an apple orchard. Eur. J. Agron. 2015, 63, 97-104. [CrossRef]

49. Saiz, G.; Green, C.; Butterbach-Bahl, K.; Kiese, R.; Avitabile, V.; Farrell, E.P. Seasonal and spatial variability of soil respiration in four Sitka spruce stands. Plant Soil 2006, 287, 161-176. [CrossRef]

50. Liu, J.; Jiang, P.; Wang, H.; Zhou, G.; Wu, J.; Yang, F.; Qian, X. Seasonal soil $\mathrm{CO}_{2}$ efflux dynamics after land use change from a natural forest to Moso bamboo plantations in subtropical China. For. Ecol. Manag. 2011, 262, 1131-1137. [CrossRef]

51. Wang, C.; Yang, J.; Zhang, Q. Soil respiration in six temperate forests in China. Glob. Chang. Biol. 2006, 12, 2103-2114. [CrossRef]

52. Jia, B.; Zhou, G.; Wang, Y.; Wang, F.; Wang, X. Effects of temperature and soil water-content on soil respiration of grazed and ungrazed Leymus chinensis steppes, Inner Mongolia. J. Arid. Environ. 2006, 67, 60-76. [CrossRef]

53. Xie, H.-H.; Fan, J.; Qi, L.-B.; Hao, M.-D. Seasonal characteristics of soil respiration and affecting factors under typical vegetations in the water-wind erosion crisscross region of the Loess Plateau. Environ. Sci. 2010, 31, 164-172. [CrossRef]

54. Zhao, Z.M.; Zhao, C.Y.; Yan, Y.Y.; Li, J.Y.; Li, J.; Shi, F.Z. Interpreting the dependence of soil respiration on soil temperature and moisture in an oasis cotton field, central Asia. Agric. Ecosyst. Environ. 2013, 168, 46-52. [CrossRef]

55. Hanson, P.; Edwards, N.; Garten, C.; Andrews, J. Separating root and soil microbial contributions to soil respiration: A review of methods and observations. Biogeochemistry 2000, 48, 115-146. [CrossRef]

56. Smith, D.L.; Johnson, L. Vegetation-mediated changes in microclimate reduce soil respiration as woodlands expand into grasslands. Ecology 2004, 85, 3348-3361. [CrossRef]

57. da Cunha, J.M.; Campos, M.C.C.; Gaio, D.C.; de Souza, Z.M.; Soares, M.D.R.; da Silva, D.M.P.; Simões, E.L. Spatial variability of soil respiration in Archaeological Dark Earth areas in the Amazon. Catena 2018, 162, 148-156. [CrossRef]

58. Yim, M.H.; Joo, S.J.; Shutou, K.; Nakane, K. Spatial variability of soil respiration in a larch plantation: Estimation of the number of sampling points required. For. Ecol. Manag. 2003, 175, 585-588. [CrossRef]

59. Barba, J.; Yuste, J.C.; Martínez-Vilalta, J.; Lloret, F. Drought-induced tree species replacement is reflected in the spatial variability of soil respiration in a mixed Mediterranean forest. For. Ecol. Manag. 2013, 306, 79-87. [CrossRef]

60. Hernández-Montes, E.; Escalona, J.; Tomás, M.; Medrano, H. Influence of water availability and grapevine phenological stage on the spatial variation in soil respiration. Aust. J. Grape Wine Res. 2017, 23, 273-279. [CrossRef]

61. Wang, W.; Zeng, W.; Chen, W.; Yang, Y.; Zeng, H. Effects of Forest Age on Soil Autotrophic and Heterotrophic Respiration Differ between Evergreen and Deciduous Forests. PLoS ONE 2013, 8, e80937. [CrossRef]

62. Rodeghiero, M.; Cescatti, A. Main determinants of forest soil respiration along an elevation/temperature gradient in the Italian Alps. Glob. Chang. Biol. 2005, 11, 1024-1041. [CrossRef]

63. Merbold, L.; Ziegler, W.; Mukelabai, M.M.; Kutsch, W.L. Spatial and temporal variation of $\mathrm{CO}_{2}$ efflux along a disturbance gradient in a miombo woodland in Western Zambia. Biogeosciences 2011, 8, 147-164. [CrossRef]

64. Smith, V. Soil respiration and its determinants on a sub-Antarctic island. Soil Biol. Biochem. 2003, 35, 77-91. [CrossRef]

65. Wang, X.; Jiang, Y.; Jia, B.; Wang, F.; Zhou, G. Comparison of soil respiration among three temperate forests in Changbai Mountains, China. Can. J. For. Res. 2010, 40, 788-795. [CrossRef]

66. Chen, H.; Tian, H.-Q. Does a General Temperature-Dependent $\mathrm{Q}_{10}$ Model of Soil Respiration Exist at Biome and Global Scale? J. Integr. Plant Biol. 2005, 47, 1288-1302. [CrossRef]

67. Conant, R.T.; Dalla-Betta, P.; Klopatek, C.C.; Klopatek, J.M. Controls on soil respiration in semiarid soils. Soil Biol. Biochem. 2004, 36, 945-951. [CrossRef]

68. Smith, V. Moisture, carbon and inorganic nutrient controls of soil respiration at a sub-Antarctic island. Soil Biol. Biochem. 2005, 37, 81-91. [CrossRef]

69. Janssens, I.A.; Pilegaard, K. Large seasonal changes in $\mathrm{Q}_{10}$ of soil respiration in a beech forest. Glob. Chang. Biol. 2003, 9, 911-918. [CrossRef]

70. Yang, Q.P.; Xu, M.; Liu, H.S.; Wang, J.S.; Liu, L.X.; Chi, Y.G.; Zheng, Y.P. Impact factors and uncertainties of the temperature sensitivity of soil respiration. Acta Ecol. Sin. 2011, 31, 2301-2311.

71. Parkin, T.B.; Kaspar, T.C. Temperature Controls on Diurnal Carbon Dioxide Flux. Soil Sci. Soc. Am. J. 2003, 67, 1763-1772. [CrossRef]

72. Wang, Y.; Liu, F.; Andersen, M.N.; Jensen, C.R. Carbon retention in the soil-plant system under different irrigation regimes. Agric. Water Manag. 2010, 98, 419-424. [CrossRef]

73. Manzoni, S.; Schimel, J.P.; Porporato, A. Responses of soil microbial communities to water stress: Results from a meta-analysis Ecology 2012, 93, 930-938. [CrossRef]

74. Pawlowski, M.N.; Crow, S.E.; Meki, M.N.; Kiniry, J.R.; Taylor, A.D.; Ogoshi, R.; Youkhana, A.; Nakahata, M. Field-Based Estimates of Global Warming Potential in Bioenergy Systems of Hawaii: Crop Choice and Deficit Irrigation. PLoS ONE 2017, 12, e0168510. [CrossRef]

75. Rochette, P.; Flanagan, L.B. Quantifying rhizosphere respiration in a corn crop under field conditions. Soil Sci. Soc. Am. 1997, 61, 466-474. [CrossRef]

76. Tu, C.; Li, F.-D.; Qiao, Y.-F.; Zhu, N.; Gu, C.-K.; Zhao, X. Effect of experimental warming on soil respiration under conventional tillage and no-tillage farmland in the North China Plain. J. Integr. Agric. 2017, 16, 967-979. [CrossRef] 
77. de OliveiraSilva, B.; Moitinho, M.R.; de Araújo Santos, G.A.; De Bortoli Teixeira, D.; Fernandes, C.; La Scala, N., Jr. Soil CO 2 emission and short-term soil pore class distribution after tillage operations. Soil Tillage Res. 2019, 186, 224-232. [CrossRef]

78. Dossou-Yovo, E.R.; Brüggemann, N.; Ampofo, E.; Igue, A.M.; Jesse, N.; Huat, J.; Agbossou, E.K. Combining no-tillage, rice straw mulch and nitrogen fertilizer application to increase the soil carbon balance of upland rice field in northern Benin. Soil Tillage Res. 2016, 163, 152-159. [CrossRef] 